\title{
Cognitive financial constraints and firm growth
}

\author{
Jun Du $\cdot$ Bach Nguyen
}

Accepted: 3 May 2021 /Published online: 15 June 2021

(C) The Author(s) 2021

\begin{abstract}
This study distinguishes entrepreneurs' cognitive financial constraints from financial supply constraints and assesses their relative importance to small business growth. Drawing from the literature on cognitive styles and institutional theory, we argue that small businesses' financial constraints derive not only from financial market failures but also from the cognitive factors of entrepreneurs. Analysing a comprehensive dataset of more than 200,000 small businesses in Vietnam, we show that both financial supply and cognitive financial constraints impede firm growth. Given this significantly deleterious effect, the cognitive financial constraints originating from the demand side of firm financing deserve more attention.
\end{abstract}

Keywords Cognitive styles · Financial constraints · Small businesses $\cdot$ Entrepreneurial performance . Emerging economies

\footnotetext{
J. Du

Lloyds Banking Group Centre for Business Prosperity (LBGCBP), Aston Business School, Aston University, Birmingham B47ET, UK

e-mail: j.du@aston.ac.uk

B. Nguyen $(\bowtie)$

University of Economics Ho Chi Minh City,

Ho Chi Minh City, Vietnam

e-mail: bachnd@ueh.edu.vn

B. Nguyen

Aston Business School, Aston University,

Birmingham B47ET, UK
}

\begin{abstract}
JEL Classifications $\quad \mathrm{D} 91 \cdot \mathrm{M} 13 \cdot \mathrm{P} 34 \cdot \mathrm{L} 26$
\end{abstract}
\section{Introduction}

Few small businesses can obtain bank loans that are sufficient for their investment needs (Carreira \& Silva, 2010). This issue, known as financial constraints, originates from market failures caused by informational asymmetries, adverse selection, and moral hazard (Bond \& Meghir, 1994). Small businesses are particularly prone to financial constraints because they lack established track records and adequate collateral (Baumann \& Kritikos, 2016). Also, financial intermediaries typically fix return rates to level off the risk of lending, which means that interest rates for small businesses tend to be higher than market equilibrium rates. Costly finance therefore forces entrepreneurs to scale down their investments in line with the funding that is available and affordable; this is generally suboptimal, which hampers their growth (Guariglia et al., 2011).

While this funding gap has been addressed in existing studies, there is another funding gap that is less familiar but which also contributes to the binding of the growth of small businesses. This second funding gap largely derives from the lack of demand from entrepreneurs. Anecdotal and empirical evidence suggests that entrepreneurs can have a conservative mindset and risk-averse attitude, and show low motivation for upscaling (Barton \& Gordon, 1987; Hutchinson, 1995). Entrepreneurs' biased cognitions could psychologically 
constrain their pursuit of external finance (Cassar, 2010). This lack of positive entrepreneurship results in sluggish operations and reduced motivation for growth, both of which diminish the desire to take out bank loans. In this situation, entrepreneurs will adjust (i.e. scale down) their investments and operations to suit the availability of internally generated funds (Guariglia, 2008). This raises an interesting question: are entrepreneurs themselves cognitively bound for growth opportunities?

As Fraser et al. (2015) claim, differentiating between these two forms of funding gap matters because we may think we are analysing financial constraints when we are, in fact, dealing with cognitive (and motivational) constraints. Although financial constraints and cognitive/motivational constraints are similar in their growth-binding consequences, they require vastly different remedies. Unfortunately, however, they are largely undistinguished in the extant literature.

This study aims to fill this gap by examining the issue of finance from the demand perspective. We first conceptualise entrepreneurial cognitive financial constraints and discuss their nature by building on two sets of theoretical perspectives: transaction cost theory and institutional theory. Then, we specifically examine the extent to which cognitive financial constraints affect small firm growth.

While both financial supply constraints and cognitive financial constraints have a negative impact on firm growth, we argue that a reduction in cognitive financial constraints gives rise to a higher growth rate than that which is generated by a reduction in financial constraints. This is because although financial constraints may substantially reduce the growth rate, cognitive financial constraints appear to inhibit the desire for growth (Fraser et al., 2015). Financially constrained firms may cleverly manage their working capital, procure trade credits, or utilise informal external financing sources to sustain their operations; by contrast, firms that are cognitively constrained do not.

We test our framework in the context of Vietnam, an ideal setting for the following reasons. First, as a post-communist economy, Vietnam's government still controls most of the country's key strategic resources, including the banking and financial markets (Nguyen et al., 2018a, 2018b). The institutional arrangements of the country remain strongly biased against the private sector (Nguyen \& van Dijk, 2012), creating substantial discrimination and transaction costs in the processing of bank loan applications. As a result, small private businesses suffer significant financing constraints as well as motivational constraints. Second, Vietnam is an emerging economy that is characterised by a booming entrepreneurial sector (i.e. young and small private businesses). These firms are the key drivers of Vietnam's phenomenal economic transformation over the last decade (Santarelli \& Tran, 2016). Therefore, an analysis of their cognitive financial constraints is essential to enabling them to further boost their contributions to the economy. Although a within-country research setting sets a boundary condition to our findings, the context of Vietnam allows us to identify the significance of cognitive financial constraints and draw inferences that are relevant to other developing economy environments.

We empirically test our hypotheses with a dataset of more than two hundred thousand small businesses in Vietnam over the period of 2010-2012, and link this to a unique and comprehensive survey on firm financing in 2011. The empirical model controls for potential endogeneity-related issues using Wooldridge's (2015) modified control function technique, multilevel modelling, and matching approaches.

This study contributes to the existing literature in several ways. First, we go beyond the conventional framework for analysing financial supply constraints by proposing a mechanism from the financial demand side that accounts for the prevailing suboptimal growth rate of small businesses. The extant literature endorses the assumption that small firms always need loans and cannot obtain them because the financial markets are imperfect (Bond \& Van Reenen, 2007). This study steers the research focus towards the demand side, increasing our understanding of the mechanisms and effects of cognitive financial constraints on small firm growth.

Our empirical findings highlight the effect of reducing cognitive financial constraints on firm growth. Our focal hypothesis is that firms with an intention to borrow, even if they have not actually applied for bank loans, perform significantly better than firms that do not want to borrow. This growthstimulating effect stems from the easing of cognitive financial constraints, something that requires no additional finance to boost growth. Drawing from our key findings, we call for businesses and policymakers to give attention to the issue of cognitive financial 
constraints, and to devote resources to help entrepreneurs overcome their cognitive constraints through education, training, and mentoring, thereby enhancing firm growth.

This paper is structured as follows: Section 2 summarises related literature and build up hypotheses. Then, Section 3 illustrates the data in use, variables, and econometric settings. Section 4 presents the results. Finally, Section 5 discusses the findings in relation to the extant literature and concludes the paper.

\section{Literature and hypotheses}

The existing body of literature predominantly approaches financial constraints from the perspective of the supply side of finance. This has been the case since long before the 2008 financial crisis when many economies experienced a significant reduction in the flow of bank loans into small businesses, especially in emerging countries (Fraser et al., 2015). The research focus on financial supply has clearly improved our understanding of how the frictions that emanate from asymmetric information and agency costs have created constraints on small- and mediumsized enterprises (SMEs) concerning their access to external loans. To be more specific, these constraints are financial supply constraints, in that they refer to the situation where the lack of financial supply means that a firm cannot obtain sufficient external funds to support its operations. Financial supply constraints have been widely investigated and are found to have a negative impact on firm investments, performance, and growth (Carreira \& Silva, 2010). This line of work is founded on the underlying assumption that small businesses always need external finance, and that once this becomes available, it will lead to improved performance and growth.

However, the piece that is missing from this picture is that not all small businesses apply for bank loans. From the demand side, there is another type of constraints on a firm's access to external finance: $\operatorname{cog}$ nitive financial constraints. In this situation, the firm does not obtain sufficient external funds to support its operations because the entrepreneur has cognitive barriers to obtaining finance rather than because the funds are unnecessary or inaccessible. Hence, it is the entrepreneur's state of mind that constrains him or her from pursuing financial access. Such entrepreneurs will not actively seek out external loans even if the financial supply constraint problems are mitigated.

As financial supply constraints and entrepreneurial cognitive financial constraints both contribute to the funding gap, it is important to treat the two differently and to design-specific solutions for each (Fraser et al., 2015).

\subsection{Cognitive financial constraints}

\subsubsection{Cognitive styles and entrepreneurship}

Entrepreneurship cognition was first studied by Comegys (1976) and more fully developed into a conceptual framework for studying organisations by Scott $(1995,2014)$. This strand of research tries to understand how cognitive factors affect human actions and, more specifically, to understand the individual's role in the entrepreneurial process (Baron, 2006). The entrepreneur's cognitive style refers to an individual's preferred way of gathering, processing, and evaluating information related to creativity, problem-solving, and decision-making. So, what factors shape entrepreneurial cognitive style? Founded in cognitive science, the research on entrepreneurship cognition has identified factors at individuals, organisations (e.g. groups or firms), and/or more broadly contextual bodies (e.g. markets, societies, or nations) to influence several entrepreneurship dimensions, and thus has implications for entrepreneurial action.

At the individual level, the literature identifies that an entrepreneur's personal characteristics and past experience are key elements of the cognitive resources that influence decision-making in the entrepreneurial process. Knowledge, in particular, is identified as the key cognitive resource for entrepreneurship (Politis, 2005). Next, for the power of the organisation an individual owns or is affiliated to, its culture, social networks, and supportive mechanisms can empower individual entrepreneurs or bind them. For example, being in businesses that are older or have more successful financial track records improves the chances of an entrepreneur's perceived success in securing external funding (Carter et al. 2015). The third level of influence lies at a contextual level. This layer focuses on how external 
environmental factors, such as formal and informal institutions, influence the individual's subjective perceptions, interpretations, and other mental representations of informational signals (Boudreaux et al., 2019). For example, it has been found that entrepreneurs' perceptions of corruption and the governance quality of local authorities may enhance firm investment and performance in Vietnam (Nguyen, 2019; Nguyen et al., 2018a, 2018b).

In sum, the literature explains that contextual factors influence the development of entrepreneurial cognitive styles, some of which may constrain entrepreneurs from making risky decisions, including seeking external financing.

\subsubsection{Cognitive financial constraints and firm growth}

If it is the entrepreneur's cognitive style rather than an inadequate supply of finance that is mainly responsible for the under-financing of the firm, the business will suffer from cognitive financial constraints. In this situation, entrepreneurs express their reluctance to seek out external finance in claims such as "I do not want loans". For analytical purposes, we refer to this type of business as one that suffers from cognitive financial constraints.

By contrast, entrepreneurs who actively apply for bank loans may suffer different financial constraints. Their initial applications are likely to be unsuccessful but firms that persevere may be given bank loans, albeit at a level too small to meet their demands and thus they are dissatisfied with the loans (i.e. the firm is financially constrained). Eventually, when informational asymmetries are substantially mitigated, they can gain full access to the requisite amount of funding and become satisfied with the values of loans they obtain (i.e. they become financially unconstrained firms).

It is noteworthy that for these firms, regardless of whether they are granted loans or of how sufficient the loans are for their needs, or even if they merely form the intention of applying for loans, their cognitive financial constraints are significantly lower than those of entrepreneurs who are in the stage of "I do not want loans". We argue that for entrepreneurs who successfully overcome their cognitive financial constraints to (want to) obtain external financing, even if this financing is insufficient, their businesses will perform better than those of the entrepreneurs whose entrepreneurial styles and risk perceptions constrain them within a safe and comfortable zone.

In the following sections, we derive our hypotheses by comparing the growth potential of four groups of firms: (1) cognitively financially constrained, (2) cognitively financially unconstrained, (3) financially constrained, and (4) financially unconstrained.

There are at least two reasons that externally financed firms may outperform the firms that are wholly internally financed. First, for firms borrowing from formal financial institutions (e.g. banks), their operations and decision-making processes will be scrutinised and monitored according to pre-agreed contracts with the financial suppliers (Claessens, 2006). This system could substantially reduce the potential tendency of entrepreneurs to overconfidence, thus improving their productivity and business growth (Invernizzi et al., 2017).

Second, bank loans are legal obligations that impose financial burdens on entrepreneurs and force them to focus on boosting performance (Ayyagari et al., 2010). Many banks ask for collateral (e.g. saving accounts, home-based lending) from entrepreneurs, or insert unlimited personal liability clauses into the borrowing agreement (Anwar \& Nguyen, 2011). These potential financial risks would act as pressures that are likely to stimulate performanceenhancement through efficiency, innovations, and productivity.

Furthermore, firms that are adequately financed through bank loans (firms satisfied with loans) are expected to outperform those with inadequate access to finance (firms dissatisfied with loans). This is because having sufficient finance is more likely to help firms to operate, upscale, and invest in their operations compared to those whose external financing is suboptimal. Therefore, we propose:

Hypothesis H1: Firms that are financially unconstrained (i.e. borrowing and satisfied with bank loans) achieve higher growth than firms experiencing cognitive financial constraints (i.e. do not want to obtain bank loans).

Hypothesis H2: Firms that are financially constrained (i.e. borrowing from banks and are not satisfied) achieve higher growth than firms expe- 
Fig. 1 The process of reducing financial cognitive constraints

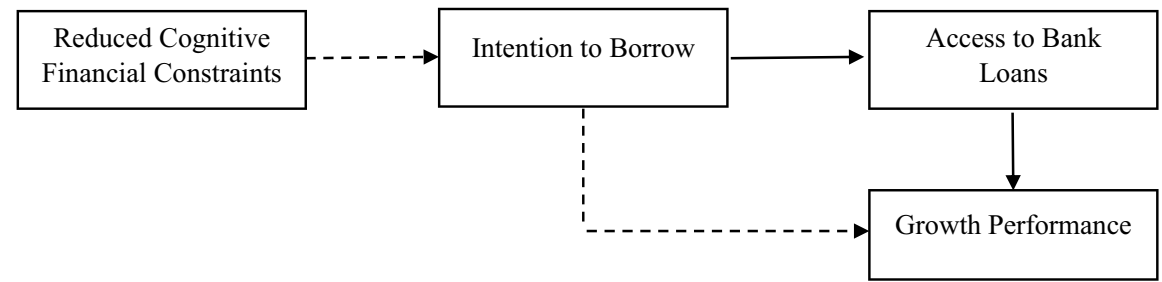

riencing cognitive financial constraints (i.e. do not want to obtain bank loans).

While the positive effect on firm performance of access to bank loans is hardly new in the extant literature, the influence that a simple intention to take out bank loans exerts on firm performance has not been widely discussed. Cognitive financial constraints occur when entrepreneurs do not actively seek out external loans, even when there is a clear need to do so. This cognitive pattern distinguishes entrepreneurs who do not want to borrow from those who intend to do so despite their application having little chance of success. The distinction between the two groups has key implications for firm growth performance.

First, entrepreneurs with lower levels of cognitive financial constraints are more active in seeking out external finance; their cognitions are structured towards a willingness to take (calculated) risks and to actively weight their utility on growth and performance-based standards (Baron, 2007; Mitchell et al., 2002). This constructive cognitive pattern may involve the entrepreneur in reflecting on his or her knowledge, skills, prior education, and experiences. When experience and knowledge are efficiently transformed into entrepreneurial intentions and alertness, entrepreneurs may improve their pattern-recognition ability, which is a crucial input for identifying higher quality business opportunities (Baron, 2006). Where internal funding capacity allows, some ideas may be immediately acted upon, leading to improvements in growth performance.

Second, entrepreneurs with lower levels of cognitive financial constraints are more likely than their cognitively financially constrained counterparts to strive to boost their business productivity. This could be in the form of restructuring of organisations, production, operations, and management (Hessels et al., 2008). These improvements trigger better performance results and growth rates without requiring additional financial input. Furthermore, a reduction in cognitive financial constraints may encourage entrepreneurs to conduct riskier but more rewarding activities (e.g. R\&D, international trading) that are essential boosters of performance and growth (Guariglia \& Liu, 2014).

Third, some entrepreneurs may purposely improve their ex ante performance (at the preloan application stage) to increase their chances of successfully obtaining bank loans. Entrepreneurs generally grasp that their small ventures typically have inadequate track records and short operation histories (Du et al., 2015). They understand that such informational asymmetries and possible agency costs may hinder their access to loans unless they are, to some extent, able to prove their ability to repay loans by demonstrating excellent performance prior to making the application (Carreira \& Silva, 2010).

Figure 1 summarises our arguments graphically. The model shows that firms can improve their performance through the use of bank loans or even by simply wanting to use bank loans. The solid arrows show the route with financial effects and the dashed arrows show the route without financial effects. It is noticeable that in both cases, growth performance only improves when there is a reduction in entrepreneurial cognitive financial constraints.

Consequently, when cognitive financial constraints are alleviated, entrepreneurs actively take on new opportunities, efficiently enhance productivity, and purposefully improve performance. Therefore, we posit the following hypothesis:

Hypothesis H3: Firms that are not cognitively financially constrained (i.e. have an intention to take out bank loans), even where they have not yet made an application, achieve higher growth than firms that are cognitively financially constrained (i.e. do not want to obtain bank loans). 
2.2 The relative importance of cognitive financial constraints

To facilitate the investigation of the relative importance of cognitive financial constraints and financial supply constraints, we briefly summarise the literature on financial supply constraints.

\subsubsection{Financial supply constraints}

Financial supply constraints are a critical impediment to small business growth and are rooted in market failures; the costs of screening and monitoring small businesses, which are typically informationally deficient and opaque, are higher than for well-established firms (Bond \& Van Reenen, 2007).

In theory, financial supply constraints may negatively affect small business performance for three reasons. First, financially constrained firms may opt to use working capital as a (temporary) funding source for urgent fixed-asset investment requirements. Fazzari and Petersen (1993) suggest that in circumstances of financial constraints, working capital needs to compete with fixed investment for a limited pool of finance. The inevitable result of smoothing fixed investment with working capital is a downturn in the firm's existing operations, production, and sales.

Second, financial constraints may substantially hinder innovation activities that are essential to the development of small businesses. For example, R\&D activities are high risk in nature; as such, entrepreneurs may find it difficult to secure external funds for activities whose outcomes are uncertain and sometimes even unprofitable (Block, 2012). Moreover, Anton and Yao (2002) argue that entrepreneurs are often reluctant to fully reveal their potential innovation plans to external lenders in an attempt to keep them from being divulged to competitors.

Third, financially constrained firms must forgo business opportunities that exceed the scope of their financial resources (Carpenter \& Guariglia, 2008). When firms do not obtain the required level of bank loan funding, they have no choice but to scale down their investment projects in line with the funding actually available to them. Moreover, in practice, some projects are non-scalable, leaving firms with two options: to invest or not (Cleary et al., 2007).

Given these adverse effects of financing supply constraints, the extant literature establishes that less financially constrained firms achieve higher performance and growth than their more financially constrained counterparts. In this study, we will re-test this well-established hypothesis in the context of Vietnam and use the result as a benchmark for the influence of cognitive financial constraints on firm performance, which is the key interest of our study.

\subsubsection{Financial supply constraints vs cognitive financial constraints}

Given that the nature of cognitive financial constraints is largely unexplored (Fraser et al., 2015), the relative importance of financial (supply) constraints and cognitive financial constraints remains unknown. Even though it has been well-documented in the extant literature that financial supply constraints shackle young and small businesses, we propose that cognitive financial constraints may play an even more pronounced role in the long-term growth prospect of SMEs. Table 1 summarises the key arguments of this proposition.

There are at least three crucial reasons for suggesting that cognitive financial constraints are more debilitating for firms than financial supply constraints.

First, entrepreneurs in financial supply constraint circumstances may find alternative solutions when they cannot obtain sufficient bank loans. For example, they can make use of informal or semi-formal financing sources (Ayyagari et al., 2010) or decide to conduct incremental investment projects, or at the very least ensure they stay productive and innovative for the sake of future loan applications. However, entrepreneurs with cognitive financial constraints rarely find other ways of obtaining additional finance, and thus, their firms are condemned to poor performance and growth. Furthermore, firms run by entrepreneurs with cognitive financial constraints are unlikely to invest their internal funds. More importantly, they are bound in a stagnating status, which is a more serious impediment to their growth than that which would be posed by a simple lack of finance (Hessels et al., 2008).

Second, the cognitive biases of entrepreneurs with cognitive financial constraints lead them to perceive as lower the utility associated with their ventures' growth and the costs associated with potential failures as higher (than the entrepreneurs without cognitive biases). For example, cognitive financially 
Table 1 Distinguishing cognitive financial constraints from financial supply constraints

\begin{tabular}{|c|c|c|}
\hline & Cognitive financial constraints & Financial supply constraints \\
\hline Theory applied & $\begin{array}{l}\text { - Institutional theory, psychology, entre- } \\
\text { preneurship, and management science }\end{array}$ & - Theory of financial constraints \\
\hline Definition & $\begin{array}{l}\text { - The situation in which entrepreneurs do } \\
\text { not want to take out bank loans }\end{array}$ & $\begin{array}{l}\text { - The situation in which firms do not obtain } \\
\text { sufficient bank loans }\end{array}$ \\
\hline Origins of the constraints & $\begin{array}{l}\text { - Biased cognitions and perceptions of } \\
\text { individuals concerning entrepreneurship } \\
\text { - Demand side of the financial market }\end{array}$ & $\begin{array}{l}\text { - Frictions from the debt markets including } \\
\text { market failures leading to the funding gap } \\
\text { - Supply side of the financial market }\end{array}$ \\
\hline $\begin{array}{l}\text { Alternative solutions to overcome the } \\
\text { constraints }\end{array}$ & - No alternative solutions & $\begin{array}{l}\text { - Other informal financing sources, e.g. } \\
\text { friends and family who could, to some } \\
\text { extent, substitute for bank loans, enabling } \\
\text { potential growth }\end{array}$ \\
\hline Benefits of alleviating the constraints & $\begin{array}{l}\text { - The financial effects of starting borrow- } \\
\text { ing: more investment leading to higher } \\
\text { growth } \\
\text { - The non-financial effects of improved } \\
\text { productivity, innovation, and entrepre- } \\
\text { neurial proactiveness leading to higher } \\
\text { growth }\end{array}$ & $\begin{array}{l}\text { - The financial effects of more borrowing: } \\
\text { more investment leading to higher growth }\end{array}$ \\
\hline Consequence of persistent constraints & - Impede growth & - Reduce growth rate \\
\hline Length of the effects & $\begin{array}{l}\text { - Long-term (may be concerned with } \\
\text { changing norms, beliefs, and values) }\end{array}$ & $\begin{array}{l}\text { - Short and medium terms (concerned with } \\
\text { changing regulations) }\end{array}$ \\
\hline The relative importance & - Necessity condition for growth & - Sufficient condition for growth \\
\hline $\begin{array}{l}\text { Practical methods to eliminate the con- } \\
\text { straints }\end{array}$ & $\begin{array}{l}\text { - Enhance entrepreneurial education } \\
\text { - Improve local government quality, boost } \\
\text { levels of trusts in government }\end{array}$ & $\begin{array}{l}\text { - Liberalise the banking system } \\
\text { - Organise financial subsidies for small } \\
\text { businesses }\end{array}$ \\
\hline
\end{tabular}

constrained entrepreneurs tend to amplify the social and psychological costs of failures (Liu et al., 2019). This cognitive pattern makes small firms generally settle for survival rather than hanker for growth (Cressy \& Olofsson, 1997). Meanwhile, financially constrained firms, by definition, are firms that wish to grow but are unable to gain sufficient capital to fund their activities (e.g. their investment projects). As a result, financially constrained firms are more likely to take on the opportunities that their available funds can accommodate, whereas entrepreneurs with cognitive financial constraints may choose to ignore/deny such opportunities. Therefore, it could be expected that cognitive financial constraints are more growthbinding than financial constraints.

Third, we posit that entrepreneurs with cognitive financial biases may also suffer from emotional biases. Thus, even if the entrepreneurs manage to successfully overcome their cognitive biases, they may still lack the motivation to grow their firms. The motivational aspect of cognitive financial constraints may deter entrepreneurs from actively engaging in innovation and business-expanding activities. Also, they are more selective in information gathering and processing in that they focus on information that maintains their status quo. They are reluctant to seek advice from others and less likely to explore alternative problem-solving solutions (Liu et al., 2019). One of the most important motivational constructs of entrepreneurship is the aspiration for growth. Low growth aspiration is a state in which entrepreneurs lack the motivation to grow their business to a considerable scale (Efendic et al., 2015). A low level of growth aspiration has been documented in the empirical literature as exerting a negative influence on subsequent growth (Estrin et al., 2013).

In sum, entrepreneurs with cognitive financial constraints suffer from cognitive biases and emotional biases, and they lack the motivation to seek alternative external finance. Conversely, financially constrained firms stay alert to business opportunities and may actively seek alternative finance to support their growth prospects. As such, we suggest that: 
Hypothesis H4: Cognitive financial constraints have a stronger growth-binding effect on small businesses than financial supply constraints have.

\section{Data and method}

\subsection{Data}

We employ the Enterprise Annual Survey conducted by the Vietnam General Statistics Office (GSO) to test the proposed hypotheses. The dataset provides comprehensive and rich firm-level information, including ownership and owners' characteristics; firm employment; capital structure; and performance for the manufacturing, mining, and service industries. The survey was first conducted in 2000 and has been carried out on a national scale every year since then. As such, this is comprehensive and representative panel data showing the general characteristics of several types of business operating in Vietnam. The sample of surveyed firms increases year on year, with a sharp expansion in the number of newly established businesses: the sample of observations in 2000 was approximately 40,000 firms. This increased to more than 500,000 firms in the 2016 dataset.

In 2011, three years after the global crisis, there was a one-off supplementary questionnaire concerning firm financing. These additional questions provide a rare opportunity for the construction of variables that identify whether a company is experiencing (1) financial supply constraints, (2) cognitive financial constraints, or (3) no financial constraints. The specific questions asked in the survey and the operationalisation of these variables are discussed in detail in the next section, where we describe the independent variables.

Moreover, we also employ variables at the regional level to control for the confounding effects of regional characteristics on firm growth. These variables are the construction values, consumption values, number of foreign direct investments, and number of state-owned firms in the province. To do so, we use a set of provincial-level variables adopted from the GSO Provincial Annual Report, which are available in the 2011 Vietnam Statistic Yearbook. ${ }^{1}$ Besides

\footnotetext{
$\overline{1}$ Source: http://www.gso.gov.vn/Default_en.aspx?tabid=515
}

this, we make use of the Provincial Competitiveness Index (PCI) to control the governance quality of local governments. $^{2}$

The number of private firm observations in the study period is 258,399 . In this study, we are interested in the population of private SMEs. ${ }^{3}$ We therefore exclude large firms whose revenue structure and growth momentum are substantially different from those of small businesses (Nguyen et al., 2018a, 2018 b). After removing large firms (2.8\% of the overall sample), the number of small- and medium-sized businesses remaining is 251,164 . It is noteworthy that Vietnam is a very young economy and SMEs account for the bulk of the business sector (Nguyen \& Canh, 2020). Also, to reduce the effects of heterogeneity, we exclude the top and bottom $1 \%$ of observations in all variables. This task eliminates 18,502 observations from the sample. Therefore, the final sample available for investigation contains 232,662 firms. ${ }^{4}$

\subsection{Models}

Before investigating the effect of cognitive financial constraints, we first create a financing decision model in order to understand what factors drive them. Building on the existing literature on the conceptualisation of cognitive styles and entrepreneurship (as reviewed in the previous section), we specify the following simple model:

$$
\begin{aligned}
\text { Financing decisions }_{i g}= & \beta_{0}+\beta_{1}\left(\text { Individual factors }_{i g}\right) \\
& +\beta_{2}\left(\text { Organisational factors }_{i g}\right) \\
& +\beta_{3}\left(\text { Contextual factor }_{g}\right)+v_{j}+v_{g}+\mu_{i t}
\end{aligned}
$$

Next, we move on to examine the growth implications of cognitive financial constraints. In line with the extant literature, we propose the following reduced-form growth function:

\footnotetext{
2 The PCI data is available at http://eng.pcivietnam.org/

3 According to the Enterprise Law of Vietnam, small- and medium-sized enterprises are firms that have more than 10 but fewer than 300 employees (300 inclusive) and have total capital of less than 100 billion VND (100 billion inclusive).

${ }^{4}$ Outliers are only eliminated for continuous variables.
} 


$$
\begin{aligned}
\text { Growth }_{i g}= & \beta_{0}+\beta_{1}\left(\text { Financing decisions }_{i g}\right) \\
& +\beta_{2}\left(\text { Individual factors }_{i g}\right)+\beta_{3}\left(\text { Organisational factors }_{i g}\right) \\
& +\beta_{4}\left(\text { Contextual factor }_{g}\right)+v_{j}+v_{g}+\mu_{i t}
\end{aligned}
$$

It is noteworthy that the dependent variable Financing decisions $s_{i g}$ in Eq. (1) is the main independent variable in Eq. (2). In the following section, we will describe the variables in detail by reference to Eq. (2) since it contains, inter alia, all the components of Eq. (1). Finally, the model includes an industryspecific component $v_{j}$ and a regional-specific component $v_{g}$; these are controlled using corresponding dummies (two-digit industry dummies and 63 province dummies); and the idiosyncratic error term $\mu_{i t}$.

\subsection{Variables and summary statistics}

\subsubsection{Dependent variables}

The two primary dependent variables in Eq. (2) are revenue growth and asset growth, which are the percentage changes in sales revenue and fixed assets over two consecutive years. To be consistent with the availability of the data concerning financial supply constraints and cognitive financial constraints, which was collected for the year 2011 only, the growth rate variables in this study indicate the percentage changes in revenue and assets from 2011 to 2012. Since cognitive financial constraints are persistent over time, it is expected that the information about cognitive financial constraints in 2011 is highly relevant to the 2011-2012 growth rate. The use of growth rates instead of an absolute level of performance (e.g. revenues/profitability) could also reduce concerns with endogeneity due to unobservable firm-level characteristics and external shocks that may result in biased estimation.

Table 2 shows that in two years (2011-2012), the average revenue growth of SMEs in our sample is $3.2 \%$, while the average asset growth is $2.1 \%$. Also, the $t$-test and the Mann-Whitney $U$ test show that the revenue growth and asset growth of firms that do not want to borrow (No need) are significantly different from those of firms in the other three groups in the sense that their revenue and asset growth rates are negative on average, indicating that their businesses are shrinking. Meanwhile, the corresponding rates associated with the other groups are all positive, showing an affirmative expansion. However, the growth rates of firms that want to borrow from a bank (Intention) and firms that actually do so (Satisfied/Dissatisfied) are not significantly different. This finding initially suggests that simply intending to take on a loan may boost firm revenue growth to the same extent as actually borrowing.

\subsubsection{Independent variables}

The survey classifies the total sample of firms into two categories by the question, "Did your enterprise use bank loans in the last year?" The firms that answer "Yes" are then asked whether or not they are satisfied with the values of the loans they obtained. Firms that answer "No" are asked whether this is because they have not yet applied for a loan or if it is because they do not want to borrow. To obtain information about financial supply constraints and cognitive financial constraints, we construct the following three dummy variables. It is noteworthy that each dummy is a paircombination of the control group. The control group is "do not want to borrow" (No need group), and the three treatments are (1) borrowing and satisfied; (2) borrowing and dissatisfied; and (3) having an intention to borrow. A decision diagram is presented in Fig. 2 to illustrate the survey questions.

Referring to Eq. (2), the three independent variables of interest are constructed as follows:

Satisfied: Respondents in the financing survey indicated that they took out bank loans and were satisfied with the values of loans they obtained. Satisfied variable takes value 1 for firms that are satisfied (treatment 1 ) and value 0 for firms that do not want to borrow (control).

Dissatisfied: Respondents in the financing survey indicated that they obtained bank loans but were dissatisfied with the amounts they obtained (i.e. they need bigger loans). Dissatisfied variable takes value 1 for firms that are dissatisfied (treatment 2) and value 0 for firms that do not want to borrow (control).

Intention: Respondents indicated that they wanted to apply for bank loans but did not do so for one or more of the following reasons: insufficient collateral, do not fully understand the banking procedures, understand the procedures but feel that they 
Table 2 Variable definition and mean statistics

\begin{tabular}{|c|c|c|c|c|c|c|}
\hline Variable & Definition & Total sample & Intention & Dissatisfied & Satisfied & Lower No need \\
\hline Revenue growth & $\begin{array}{l}\text { Percentage of net revenue } \\
\text { growth in two consecutive } \\
\text { years }\end{array}$ & 0.032 & $0.067 * * * \mathrm{a}$ & $0.068 * * * a$ & $0.064 * * * a$ & -0.048 \\
\hline Asset growth & $\begin{array}{l}\text { Percentage of fixed asset } \\
\text { growth in two consecutive } \\
\text { years }\end{array}$ & 0.021 & $0.114 * * * a$ & $0.011 * * * a$ & $0.031 * * * a$ & -0.013 \\
\hline Intention & $\begin{array}{l}\text { Takes value } 1 \text { if a firm has an } \\
\text { intention to take out bank } \\
\text { loans, } 0 \text { if it does not want } \\
\text { to borrow (No need group), } \\
\text { missing otherwise }\end{array}$ & 0.257 & 1 & & & \\
\hline Dissatisfied & $\begin{array}{l}\text { Takes value } 1 \text { a firm takes out } \\
\text { bank loans and is dissatis- } \\
\text { fied (needs more loans), } 0 \text { if } \\
\text { it does not want to borrow } \\
\text { (No need group), missing } \\
\text { otherwise }\end{array}$ & 0.467 & & 1 & & \\
\hline Satisfied & $\begin{array}{l}\text { Takes value } 1 \text { if a firm takes out } \\
\text { bank loans and is satisfied, } 0 \\
\text { if it does not want to borrow } \\
\text { (No need group), missing } \\
\text { otherwise }\end{array}$ & 0.533 & & & 1 & \\
\hline Owner age & Entrepreneur age & 43.469 & $43.036 * * * a$ & $44.064 * * * a$ & $44.395 * * * a$ & 41.355 \\
\hline Owner gender & Takes value 1 if male, 0 female & 0.746 & $0.740 * * * \mathrm{a}$ & $0.773 * * * a$ & $0.745 * * * \mathrm{a}$ & 0.713 \\
\hline Owner education & $\begin{array}{l}\text { Takes value } 1 \text { no degrees, } 2 \\
\text { junior technical degrees, } 3 \\
\text { senior technical degrees, } \\
4 \text { professional vocational } \\
\text { degrees, } 5 \text { college degrees, } \\
6 \text { bachelors, } 7 \text { masters, } 8 \\
\text { doctoral level }\end{array}$ & 4.705 & 4.659 & $4.614^{\mathrm{a}}$ & $4.684 * * b$ & 4.654 \\
\hline Firm age & Firm age since establishment & 7.481 & $7.865^{* * * a}$ & $7.765 * * * a$ & $7.879 * * * \mathrm{a}$ & 6.584 \\
\hline Firm size & $\begin{array}{l}\text { Natural log of the number of } \\
\text { employees (report here the } \\
\text { number) }\end{array}$ & 39.541 & $37.516 * * * a$ & $41.134 * * * a$ & $41.996 * * * a$ & 28.356 \\
\hline Profitability & $\begin{array}{l}\text { The ratio of profit over firm } \\
\text { total assets }\end{array}$ & 0.009 & $0.004 * * * \mathrm{a}$ & $0.007 * * * a$ & $0.016 * * * a$ & -0.032 \\
\hline Asset structure & $\begin{array}{l}\text { The ratio of fixed assets over } \\
\text { firm total assets }\end{array}$ & 0.234 & $0.211 * * * \mathrm{a}$ & $0.267 * * * a$ & $0.271 * * * a$ & 0.150 \\
\hline Debt structure & $\begin{array}{l}\text { The ratio of liabilities over firm } \\
\text { total capital }\end{array}$ & 0.491 & $0.469 * * * a$ & $0.532 * * * a$ & $0.546 * * * a$ & 0.398 \\
\hline Investment & $\begin{array}{l}\text { The ratio of new investments } \\
\text { over firm total capital }\end{array}$ & 0.225 & $0.222 * * * a$ & $0.199 * * * a$ & $0.192 * * * a$ & 0.299 \\
\hline Web & $\begin{array}{l}\text { Takes value } 1 \text { if a firm has a } \\
\text { company website, } 0 \text { if no } \\
\text { website }\end{array}$ & 0.193 & 0.255 & 0.174 & 0.207 & 0.179 \\
\hline eBuy & $\begin{array}{l}\text { The values of purchasing using } \\
\text { an e-commerce platform as a } \\
\text { ratio of total revenue }\end{array}$ & 0.016 & 0.026 & 0.180 & 0.017 & 0.011 \\
\hline eSell & $\begin{array}{l}\text { The sale values of products and } \\
\text { services using an e-commerce } \\
\text { platform as a ratio of total } \\
\text { revenue }\end{array}$ & 0.033 & 0.050 & 0.034 & 0.033 & 0.026 \\
\hline
\end{tabular}


Table 2 (continued)

\begin{tabular}{|c|c|c|c|c|c|c|}
\hline Variable & Definition & Total sample & Intention & Dissatisfied & Satisfied & Lower No need \\
\hline eCommerce & $\begin{array}{l}\text { Takes value } 1 \text { if firms have } \\
\text { other activities (on top of } \\
\text { buying and selling) based } \\
\text { on e-commerce platforms, } 0 \\
\text { otherwise }\end{array}$ & 0.016 & 0.026 & 0.017 & 0.017 & 0.012 \\
\hline Provincial constructions & $\begin{array}{l}\text { Provincial construction value } \\
\text { per capita, in million VND }\end{array}$ & 8.730 & $9.796 * * * \mathrm{a}$ & $8.255^{* * * a}$ & $7.774 * * * \mathrm{a}$ & 10.039 \\
\hline Provincial consumptions & $\begin{array}{l}\text { Provincial consumption value } \\
\text { per capita, in million VND }\end{array}$ & 25.567 & $29.692 * * * a$ & $22.798 * * * \mathrm{a}$ & $22.695 * * * a$ & 31.702 \\
\hline Distance & $\begin{array}{l}\text { Distance from a province to } \\
\text { the closest economic centre, } \\
\text { in } \mathrm{km}\end{array}$ & 94.365 & $69.326 * * * \mathrm{a}$ & $111.021 * * * \mathrm{a}$ & $116.332 * * * a$ & 60.214 \\
\hline Cumulative FDI & $\begin{array}{l}\text { Cumulative FDI value per } \\
\text { capita, in billion VND }\end{array}$ & 0.671 & $0.764 * * * \mathrm{a}$ & $0.580 * * * a$ & $0.600 * * * \mathrm{a}$ & 0.827 \\
\hline SOE capital & $\begin{array}{l}\text { SOEs' registered capital value } \\
\text { per capita, in billion VND }\end{array}$ & 0.080 & $0.089 * * * \mathrm{a}$ & $0.074 * * * \mathrm{a}$ & $0.064 * * * \mathrm{a}$ & 0.087 \\
\hline Local governance quality & $\begin{array}{l}\text { Provincial Competitiveness } \\
\text { Index, } 0 \text { is the worst govern- } \\
\text { ance quality, and } 100 \text { is the } \\
\text { best }\end{array}$ & 60.978 & $61.391 * \mathrm{a}$ & $60.552 * * * a$ & $60.687 * * * a$ & 61.670 \\
\hline Observations & & 204,135 & 21,036 & 53,224 & 69,186 & 60,689 \\
\hline
\end{tabular}

The Student two-sample $t$-test and Mann-Whitney $U$ test use "Lower No need" as the benchmark. The number of observations is 204,135 small businesses. Firm-level variables are computed using the Annual Enterprise Survey of the General Statistics Office of Vietnam. Provincial-level variables are computed using the statistics from Vietnam Annual Statistic Yearbook. Provincial Competitiveness Index is obtained from http://eng.pcivietnam.org/. All values are corrected for depreciation using official GDP deflators. For the $t$-test: $* * *$ significant at $1 \%, * *$ significant at $5 \%$, *significant at $10 \%$. For the Mann-Whitney $U$ test: ${ }^{\mathrm{a}}$ significant at $1 \%$, ${ }^{\mathrm{b}}$ significant at $5 \%,{ }^{c}$ significant at $10 \%$

are time-consuming, or think that the interest rate is currently unaffordable. Intention variable takes value 1 for firms that have not applied for bank loans but want to do so (treatment 3 ) and value 0 for firms that do not want to borrow (control).
We construct each dummy as a pair comprising the control group and a specific treatment group. This setting allows us to quantify the influence of financial constraints on firm growth by investigating the difference between the coefficients associated with the

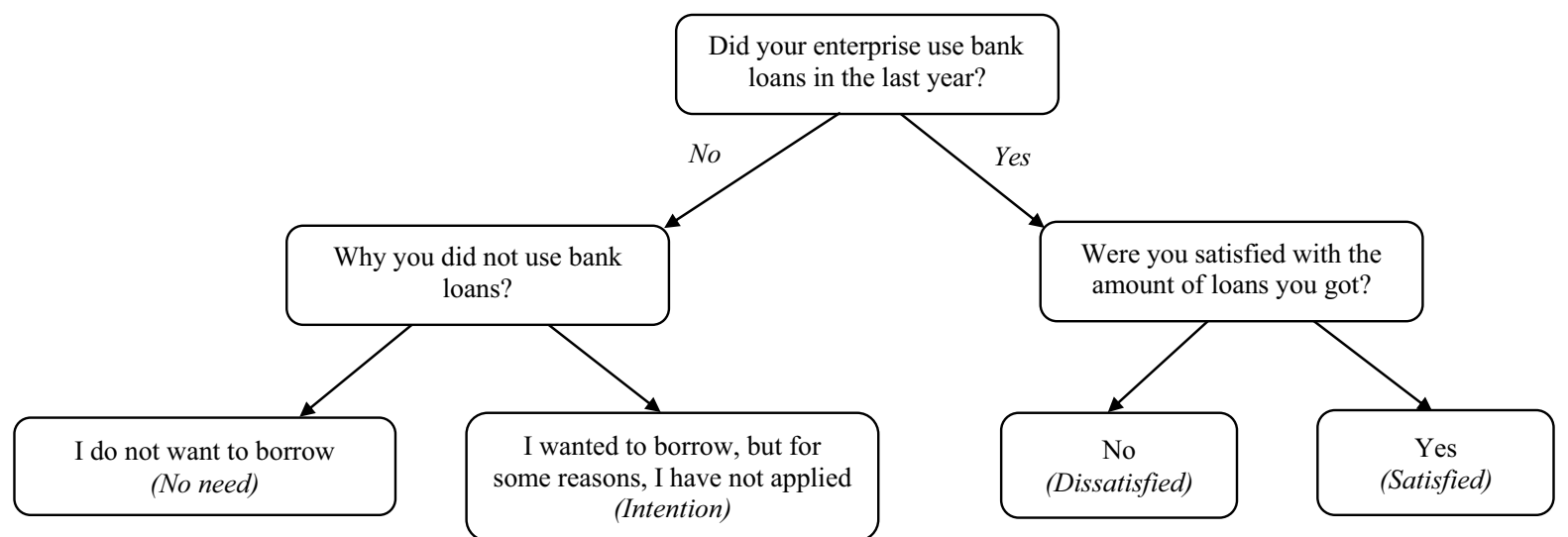

Fig. 2 Financing decision diagram 
Satisfied and Dissatisfied variables in a growth equation. Since the two treatments are compared against a single control group, the difference in their treatment effects represents the impact of being satisfied with bank loans relative to being dissatisfied with bank loans (i.e. the financial supply constraints). Meanwhile, to quantify the influence of cognitive financial constraints on firm growth, we can investigate the coefficients associated with the intention variable as this indicates a pure reduction of cognitive financial constraints without the financial effects of bank loans. In this setting, in order to evaluate the relative importance of financial supply constraints and cognitive financial constraints, we simply need to compare the difference between the effects of Satisfied and Dissatisfied with the effect of Intention.

As a robustness test, we also construct a category variable that takes value 0 for firms that do not want to borrow (No need), value 1 for firms that have an intention to borrow (Intention), value 2 for firms that borrow at a suboptimal level (Dissatisfied), and value 3 for firms that borrow the requisite amount (Satisfied).

\subsubsection{Control variables}

Pursuant to the extant literature, we include a set of covariates that may have an influence on firm growth. At the firm level, we control for firm size, firm age, profitability, asset structure, debt structure, and industry. These variables represent the firm-specific and industry-specific characteristics that significantly determine the performance, profitability, and growth rate of a firm (Zhou, 2017). Specifically, smaller/ younger firms may grow faster than their older/larger counterparts thanks to their entrepreneurial mindset and flexible operational structure (Jovanovic, 1982). Also, firms that are more profitable may have substantial resources to fund their investment projects, which can lead to faster growth rates (Nguyen, 2019). Meanwhile, asset structure is derived from the ratio of fixed assets over total assets, which is an indicator of the capital intensity of the firm. Firms that have substantial fixed assets may perform better than firms whose fixed assets are insufficient to realise their business opportunities (Baños-Caballero et al., 2010). Finally, debt structure indicates the ratio of liabilities over firm total capital. This variable takes into account the fact that externally financed firms typically achieve a higher growth rate compared to internally funded firms; this is not just because of their additional financial resources but is a product of the monitoring effects (Du et al., 2015). In addition to these variables, we include firm investment, which could serve as a proxy for the unobserved firm growth intention/orientation. Firms with a lower commitment to growth usually express a lower level of investment (Nguyen, 2018).

At the entrepreneur-level, we control for owner age, gender, and education. These individual-specific factors play an essential role in small business performance because they indicate the knowledge and experience of entrepreneurs, which may markedly influence their ability to recognise and evaluate the business opportunities that can generate a higher growth rate (Tran \& Santarelli, 2014). Specifically, older individuals typically have a set of wider/ stronger social networks that may help them obtain the information and resources essential to boosting business growth rates (Dinh et al., 2012). It has been shown that female entrepreneurs are less interested in economic performance indicators such as growth, preferring to maintain a harmonious working environment with their stakeholders (Bardasi et al., 2011). Finally, education is associated with skills and knowledge that may help entrepreneurs identify business opportunities and improve their business operation efficiency, leading to a higher growth rate (Kolstad \& Wiig, 2015).

At the provincial level, we include the variables of provincial construction and consumption value per capita to control for local market demand. These two variables represent the level of development of the local business markets. Provinces with higher levels of public construction and consumption power have more active business environments that can help facilitate local firm growth rates (Su \& Bui, 2017). We also control for cumulative state-owned enterprises (SOE) and foreign direct investment (FDI) capital, which represent the level of competitiveness of the local market. The literature has shown that the presence of foreign or state-owned enterprises could pose a severe threat to the performance of private small businesses (Thompson \& Wenyu, 2015). 
We control for the distance from a province to the closest municipal city (business and political centres) to take into account the interaction between the provinces. This variable could absorb the effects of geographical advantages on firm growth (Nguyen et al., 2018a, 2018b). Moreover, we also include an index that measures the governance quality of provincial governments to take into account the important effects of local governance. In developing countries, formal institutions are not complete and well-structured; as such, local authorities have substantial room for interpreting and executing the rules of law as per their own understanding, leading to significantly different business environments across regions within a country (Nguyen et al., 2018a, 2018b).

Table 2 presents the variable definitions and summary statistics. The summary statistics show that Vietnamese SMEs are quite young, with the average firm being 7.5 years old and having 40 employees. For this reason, they may be sensitive to local economic settings and institutional environments (Nguyen et al., 2018a, 2018b). In terms of entrepreneurs' characteristics, the average age is 43.5 years old, and nearly two-thirds of entrepreneurs are male with moderate educational backgrounds.

We also conduct a $t$-test and a Mann-Whitney $U$ test of the mean statistics for each type of firm. In general, there are significant differences in all the firm characteristics between the No need group and the other three groups, except for entrepreneurs' education. However, the differences in the asset structures and investments between firms that have an intention to take out bank loans and firms that actually do so are not statistically significant (in the $t$-test). Meanwhile, firms that intend to borrow are smaller and have a slightly lower level of profitability and debt compared to firms that have actually borrowed. These findings initially indicate that there are substantial differences in the firm-level characteristics of firms that do not want to take out bank loans and those that have an intention to borrow or actually borrow loans. However, the differences between firms that want to borrow (Intention) and firms that actually borrow bank loans (Satisfied and Dissatisfied) are not substantial. The pairwise correlation matrix is reported in Appendix
1 Table 5, which indicates no serious issues with multicollinearity in key variables.

\subsection{Estimation and econometric issues}

\subsubsection{Selection bias}

To investigate whether firms that explicitly say "I do not want bank loans" have foregone business opportunities or have instead used other sources of finance to support their operations, we divide the group into two subgroups using cash flow. Firms are classified as Lower No need if they are in the No need group (i.e. do not want bank loans) and their cash flow is lower than the mean of their peers (i.e. the entire No need group) in the same industry and same location. Such firms should need more capital if they are to invest so as to catch up with their peers. If their growth performance is lower than that of their peers, it can be interpreted that they suffer from cognitive financial constraints because they are choosing not to borrow even though this would enable them to improve their performance. If, on the other hand, their growth performance is higher than that of their peers, it can be interpreted that they have no need to borrow because they have other financing sources that boost their growth performance.

To reduce concerns with selection bias, the Lower No need group will be used as the benchmark in the main analysis when comparing results with other groups of firms. In other words, in the main analysis, we drop firms in No need group with cash flow higher than the mean of their peers (in the same industry and location). We also check the robustness of our findings (reported in the Appendix) using the full set of observations in the No Need group.

\subsubsection{Estimation}

Equation 1 Since the dependent variable is a categorical variable with four potential outcomes, multinomial logit regression appears to be the most appropriate estimator. The group Lower No need is set as the benchmark to contrast the difference between this group and the other three. We also ran two logit regressions. The first compared the two groups Lower No need and Intention, and the second compared the 
Lower No need with the rest (Intention, Satisfied, and Dissatisfied altogether). The purpose of the analysis is to identify the factors that cultivate cognitive financial constraints.

Equation 2 We anticipated problems due to the selectivity of entrepreneurs' financing conditions, and potential endogeneity due to unobservables in the equation. Moreover, firm growth may also have a reverse effect on firm financing conditions. As such, the financing decision dummies (Intention, Satisfied, and Dissatisfied) are treated as endogenous variables in this study. To address these potential issues, we applied the Wooldridge (2015) modified control function to estimate Eq. (2). This is the most appropriate approach to dealing with multiple potential endogenous regressors that are discrete choice variables.

The approach uses extra regressors to break the correlation between endogenous explanatory variables and the unobservables affecting firm growth. Specifically, in the first step, we used extra exogenous variables (instrumental variables) to account for the variations in the endogenous explanatory variables. We then replaced the error term in the growth equation with the linear projection of itself on the error term in the endogenous variable equations (the first steps' error term). The inclusion of exogenous variations induced by instrumental variables and the residuals obtained from a standard probit-reduced form can serve as the control functions for possible endogeneity (Wooldridge, 2010).

In this study, we proposed five instrumental variables (IVs) that are relevant to financial supply constraints and cognitive financial constraints but are redundant to the growth function. The first IV is South, which takes value 1 for firms located in the South of Vietnam and 0 for firms located in the North of Vietnam. This variable may relate to cognitive financial constraints because of the effects of sticky informal institutions. The 1954 war with the USA partitioned the country into two halves: the North State and the South State. While North Vietnam remained purely communist, the South was exposed to capitalism until the states unified in 1975. This historical event embedded the values of individualism, proactiveness, and risk-tolerance in entrepreneurs in the South (Nguyen et al., 2018a, 2018b). As such, entrepreneurs in the South may be less cognitively constrained and more active in financing their new investment projects using bank loans. $^{5}$

The second IV is entrepreneurs' ethnic background, which comprises three dummies: Kinh, Hoa, and other minor ethnic groups. The literature suggests that ethnic background has a significant impact on an individual's perception of entrepreneurship, entrepreneurial style, and degree of riskaversion (Agius Vallejo \& Canizales, 2016; Leong, 2016). In Vietnam, Kinh is the largest ethnic group, accounting for $86 \%$ of the population. This group mostly lives in urban cities. Hoa (Chinese immigrants) is the second-largest ethnic group and it has a strong reputation for entrepreneurship (Baulch et al., 2007; Nguyen et al., 2017a, 2017b). The other minor ethnic groups, living in remote areas, are less exposed to modern values and entrepreneurial education (Nguyen et al., 2017a, 2017b). Ethnic identity may be accompanied by entrepreneurial values and beliefs (Baulch et al., 2007) that strongly relate to attitudes to risk, and activeness in procuring financing.

The other three IVs concern e-commerce: (1) Web-takes value 1 if firms have a website, 0 otherwise; (2) eBuy-the values of purchasing using an e-commerce platform as a ratio of total revenue; (3) eSell-the sale values of products and services using an e-commerce platform as a ratio of total revenue; and (4) eCommerce-takes value 1 if firms have other activities based on e-commerce platforms, 0 otherwise. In the context of Vietnam in 2011, these variables may be highly correlated with financial supply and cognitive financial constraints because, at that time, e-commerce platforms were not widely popular in the entrepreneurial community (Wheeler, 2015). As such, the transaction values using e-commerce are insignificant compared to the values of the total revenue: $3.7 \%$ of revenue for $e B u y$ and

\footnotetext{
5 The effects of sticky entrepreneurship due to war separation in different locations are also tested and confirmed using the case of East and West Germany (Fritsch \& Mueller, 2004, 2007; Fritsch \& Wyrwich, 2014).
} 
Table 3 Precedents of financing decisions

\begin{tabular}{|c|c|c|c|c|c|}
\hline & \multicolumn{3}{|c|}{ Multinomial logit } & \multirow{2}{*}{$\begin{array}{l}\text { Logit } \\
(4)\end{array}$} & \multirow{2}{*}{$\begin{array}{l}\text { Logit } \\
(5)\end{array}$} \\
\hline & (1) & (2) & (3) & & \\
\hline & Intention & Dissatisfied & Satisfied & $\begin{array}{l}\text { Lower No need } \\
\text { vs Intention }\end{array}$ & $\begin{array}{l}\text { Lower No } \\
\text { need vs the } \\
\text { rest }\end{array}$ \\
\hline Owner age & $\begin{array}{l}1.042 \\
(0.132)\end{array}$ & $\begin{array}{l}1.564 * * * \\
(0.164)\end{array}$ & $\begin{array}{l}1.335 * * * \\
(0.128)\end{array}$ & $\begin{array}{l}1.044 \\
(0.133)\end{array}$ & $\begin{array}{l}1.352 * * * \\
(0.116)\end{array}$ \\
\hline Owner gender & $\begin{array}{l}1.152 * * * \\
(0.049)\end{array}$ & $\begin{array}{l}1.250 * * * \\
(0.042)\end{array}$ & $\begin{array}{l}1.050 \\
(0.033)\end{array}$ & $\begin{array}{l}1.140 * * * \\
(0.049)\end{array}$ & $\begin{array}{l}1.132 * * * \\
(0.032)\end{array}$ \\
\hline Education & $\begin{array}{l}1.010 \\
(0.010)\end{array}$ & $\begin{array}{l}1.066^{* * * *} \\
(0.008)\end{array}$ & $\begin{array}{l}1.053 * * * \\
(0.008)\end{array}$ & $\begin{array}{l}1.016 \\
(0.010)\end{array}$ & $\begin{array}{l}1.051 * * * \\
(0.007)\end{array}$ \\
\hline Hoa ethnic & $\begin{array}{l}1.184 \\
(0.221)\end{array}$ & $\begin{array}{l}0.854 \\
(0.138)\end{array}$ & $\begin{array}{l}0.918 \\
(0.136)\end{array}$ & $\begin{array}{l}1.215 \\
(0.229)\end{array}$ & $\begin{array}{l}0.935 \\
(0.124)\end{array}$ \\
\hline Minor ethnic & $\begin{array}{l}0.643 \\
(0.241)\end{array}$ & $\begin{array}{l}0.363 * * * \\
(0.137)\end{array}$ & $\begin{array}{l}0.318 * * * \\
(0.105)\end{array}$ & $\begin{array}{l}0.660 \\
(0.244)\end{array}$ & $\begin{array}{l}0.392 * * * \\
(0.106)\end{array}$ \\
\hline Foreign ethnic & $\begin{array}{l}0.984 \\
(0.220)\end{array}$ & $\begin{array}{l}0.994 \\
(0.163)\end{array}$ & $\begin{array}{l}0.975 \\
(0.154)\end{array}$ & $\begin{array}{l}0.992 \\
(0.225)\end{array}$ & $\begin{array}{l}0.984 \\
(0.144)\end{array}$ \\
\hline Debt structure & $\begin{array}{l}2.124 * * * \\
(0.135)\end{array}$ & $\begin{array}{l}6.671 * * * \\
(0.333)\end{array}$ & $\begin{array}{l}7.616 * * * \\
(0.359)\end{array}$ & $\begin{array}{l}1.932 * * * \\
(0.112)\end{array}$ & $\begin{array}{l}5.850 * * * \\
(0.252)\end{array}$ \\
\hline Revenue growth & $\begin{array}{l}1.074 * * * \\
(0.019)\end{array}$ & $\begin{array}{l}1.014 \\
(0.015)\end{array}$ & $\begin{array}{l}1.014 \\
(0.014)\end{array}$ & $\begin{array}{l}1.076 * * * \\
(0.021)\end{array}$ & $\begin{array}{l}1.025^{* *} \\
(0.012)\end{array}$ \\
\hline Asset structure & $\begin{array}{l}0.440 * * * \\
(0.039)\end{array}$ & $\begin{array}{l}1.034 \\
(0.063)\end{array}$ & $\begin{array}{l}1.154 * * \\
(0.066)\end{array}$ & $\begin{array}{l}0.444 * * * \\
(0.040)\end{array}$ & $\begin{array}{l}0.956 \\
(0.050)\end{array}$ \\
\hline Firm size & $\begin{array}{l}0.969 \\
(0.021)\end{array}$ & $\begin{array}{l}1.106 * * * \\
(0.019)\end{array}$ & $\begin{array}{l}1.079 * * * \\
(0.018)\end{array}$ & $\begin{array}{l}0.967 \\
(0.021)\end{array}$ & $\begin{array}{l}1.071 * * * \\
(0.016)\end{array}$ \\
\hline Web & $\begin{array}{l}1.257 * * * \\
(0.056)\end{array}$ & $\begin{array}{l}1.001 \\
(0.037)\end{array}$ & $\begin{array}{l}1.290 * * * \\
(0.045)\end{array}$ & $\begin{array}{l}1.257 * * * \\
(0.056)\end{array}$ & $\begin{array}{l}1.180 * * * \\
(0.037)\end{array}$ \\
\hline eBuy & $\begin{array}{l}1.582 * * \\
(0.308)\end{array}$ & $\begin{array}{l}1.360 * \\
(0.233)\end{array}$ & $\begin{array}{l}1.231 \\
(0.201)\end{array}$ & $\begin{array}{l}1.604 * * \\
(0.320)\end{array}$ & $\begin{array}{l}1.346^{* *} \\
(0.202)\end{array}$ \\
\hline eSell & $\begin{array}{l}0.953 \\
(0.087)\end{array}$ & $\begin{array}{l}0.977 \\
(0.083)\end{array}$ & $\begin{array}{l}0.944 \\
(0.077)\end{array}$ & $\begin{array}{l}0.997 \\
(0.096)\end{array}$ & $\begin{array}{l}0.959 \\
(0.073)\end{array}$ \\
\hline eCommerce & $\begin{array}{l}1.366 \\
(0.404)\end{array}$ & $\begin{array}{l}1.275 \\
(0.338)\end{array}$ & $\begin{array}{l}1.329 \\
(0.336)\end{array}$ & $\begin{array}{l}1.235 \\
(0.411)\end{array}$ & $\begin{array}{l}1.314 \\
(0.305)\end{array}$ \\
\hline South & $\begin{array}{l}1.391 \\
(0.688)\end{array}$ & $\begin{array}{l}12.321 * * * \\
(7.559)\end{array}$ & $\begin{array}{l}7.792 * * * \\
(4.286)\end{array}$ & $\begin{array}{l}1.313 \\
(0.637)\end{array}$ & $\begin{array}{l}5.416^{* * * *} \\
(2.138)\end{array}$ \\
\hline Provincial construction & $\begin{array}{l}1.084 * * * \\
(0.013)\end{array}$ & $\begin{array}{l}1.152^{* * *} \\
(0.010)\end{array}$ & $\begin{array}{l}1.070 * * * \\
(0.009)\end{array}$ & $\begin{array}{l}1.099 * * * \\
(0.015)\end{array}$ & $\begin{array}{l}1.104 * * * \\
(0.009)\end{array}$ \\
\hline Provincial consumption & $\begin{array}{l}0.988 * * * \\
(0.002)\end{array}$ & $\begin{array}{l}0.960 * * * \\
(0.002)\end{array}$ & $\begin{array}{l}0.969 * * * \\
(0.002)\end{array}$ & $\begin{array}{l}0.986 * * * \\
(0.002)\end{array}$ & $\begin{array}{l}0.969 * * * \\
(0.001)\end{array}$ \\
\hline Cumulative FDI & $\begin{array}{l}0.842 * * * \\
(0.029)\end{array}$ & $\begin{array}{l}0.657 * * * \\
(0.018)\end{array}$ & $\begin{array}{l}0.688 * * * \\
(0.017)\end{array}$ & $\begin{array}{l}0.847 * * * \\
(0.028)\end{array}$ & $\begin{array}{l}0.693 * * * \\
(0.016)\end{array}$ \\
\hline SOE capital & $\begin{array}{l}0.042 * * * \\
(0.024)\end{array}$ & $\begin{array}{l}0.020 * * * \\
(0.009)\end{array}$ & $\begin{array}{l}0.076 * * * \\
(0.034)\end{array}$ & $\begin{array}{l}0.022 * * * \\
(0.014)\end{array}$ & $\begin{array}{l}0.037 * * * \\
(0.015)\end{array}$ \\
\hline Local governance quality & $\begin{array}{l}1.006 \\
(0.006)\end{array}$ & $\begin{array}{l}1.025 * * * \\
(0.004)\end{array}$ & $\begin{array}{l}1.021 * * * \\
(0.004)\end{array}$ & $\begin{array}{l}1.007 \\
(0.005)\end{array}$ & $\begin{array}{l}1.021 * * * \\
(0.004)\end{array}$ \\
\hline VIF & 2.951 & 3.201 & 3.225 & 3.148 & 3.278 \\
\hline$R$-squared & 0.064 & 0.068 & 0.064 & 0.064 & 0.066 \\
\hline
\end{tabular}


Table 3 (continued)

\begin{tabular}{|c|c|c|c|c|c|}
\hline & \multicolumn{3}{|c|}{ Multinomial logit } & \multirow{2}{*}{$\begin{array}{l}\text { Logit } \\
\text { (4) }\end{array}$} & \multirow{2}{*}{$\begin{array}{l}\text { Logit } \\
(5)\end{array}$} \\
\hline & (1) & (2) & (3) & & \\
\hline & Intention & Dissatisfied & Satisfied & $\begin{array}{l}\text { Lower No need } \\
\text { vs Intention }\end{array}$ & $\begin{array}{l}\text { Lower No } \\
\text { need vs the } \\
\text { rest }\end{array}$ \\
\hline Observations & 204,135 & 204,135 & 204,135 & 81,725 & 204,135 \\
\hline \multicolumn{6}{|c|}{$\begin{array}{l}\text { The statistics reported in the table are the odds ratios. The dependent variable in columns } 1,2 \text {, and } \\
3 \text { is a category variable, which takes value } 0 \text { for Lower No need, } 1 \text { for Intention, } 2 \text { for Dissatisfied, } \\
\text { and } 3 \text { for Satisfied (Lower No need serves as the benchmark). The dependent variable in column } 4 \\
\text { is a dummy variable, which takes value } 0 \text { for Lower No need, and } 1 \text { for Intention. The dependent } \\
\text { variable in column } 5 \text { is a dummy variable, which takes value } 0 \text { for Lower No need, } 1 \text { for the other } \\
\text { three groups. All estimations include full sets of two-digit industry dummies and } 63 \text { province } \\
\text { dummies. VIF is a test of variance inflation factor. ***Significant at } 1 \% \text {, **ignificant at } 5 \% \text {, } \\
\text { *significant at } 10 \%\end{array}$} \\
\hline
\end{tabular}

$2.3 \%$ for eSell on average, and their correlations with the growth variables are therefore inconsequential. However, entrepreneurs who engaged in e-commerce demonstrate that they suffered from less financial supply constraints and cognitive financial constraints at the time.

\section{Results}

\subsection{Precedents of cognitive financial constraints}

Based on the estimates of multinomial logit model regressions of the individual entrepreneur's financing choice, as reported in Table 3, we can extract clear patterns in which individual, firmlevel, and regional-level covariates contribute to the financing decision. Columns 1-3 show the results of the multinomial logit regression on a category variable that takes value 0 for Lower No need group, value 1 for Intention, value 2 for Dissatisfied, and value 3 for Satisfied (Lower No need serves as the benchmark). Column 4 presents the result of logit regression on a dummy that takes value 0 if firms are classified in the Lower No need group and takes value 1 if firms are in the Intention group. Finally, column 5 exhibits the result of logit regression on a dummy that takes value 0 if firms are classified in the Lower No need group and value 1 if firms are in one of the other three groups. For the sake of interpretation, all statistics reported in Table 3 are the odds ratios.

At the individual level, the odds ratio associated with owner gender in the multinomial logit model is greater than 1 in all columns and statistically significant in columns 1 and 2 . This finding indicates that male entrepreneurs are more likely than female entrepreneurs to be classified in groups other than the Lower No need group. Similar results are found for the variable owner age: older entrepreneurs are more likely to be in the Dissatisfied and Satisfied groups than in the Lower No need group.

The odds ratios associated with the education variable are greater than 1 and statistically significant in columns 2, 3, and 5. This shows that entrepreneurs with higher education are more likely to take on bank loans while those with lower education are more likely to be in the Lower No need group. Meanwhile, the odds ratios associated with minor ethnics are smaller than 1 in all columns, indicating that minor ethnic entrepreneurs are more likely to be in the Lower No need group.

In general, we find that at the individual level, entrepreneurs are more likely to suffer from cognitive financial constraints (i.e. to fall within the Lower No need group) if they are women, younger, less well-educated, or belong to minor ethnic groups. People with these characteristics 
are more likely to be risk-averse and may find it difficult to expand their businesses due to their perceived inferiorities. As such, they may decide to be satisfied with their modest achievements and eschew nurturing a strong intention to develop their venturing businesses.

At the firm level, the odds ratios associated with the debt structure variable are all greater than 1 and statistically significant in all columns, indicating that firms that have taken on a higher level of debt in the past are more likely to continue to use external finance. A similar result is found for revenue growth: firms that grow faster in revenue terms are more likely to have an intention to borrow or to actually take out bank loans. In terms of asset structure, the associated odds ratio is greater than 1 and statistically significant in column 3 and is smaller than 1 in the other columns. This finding indicates that firms with higher fixed assets either do not want to borrow or are satisfied with their bank loans. Meanwhile, for firm size, the odds ratios are greater than 1 and statistically significant in columns 2, 3, and 5, showing that larger firms are more likely to take out bank loans.

For the four variables related to e-business, the odds ratios associated with variable Web (having a website) and eBuy are greater than 1 and statistically significant in most columns, indicating that firms that have websites and use Internet as a platform to purchase production materials are more likely to use external finance or at least to have an intention to use it (compared to firms in Lower No need group). However, we do not find statistically meaningful impacts of eSell and eCommerce (using the internet other than buying and selling products).

In general, at the firm level, we find that entrepreneurs are more likely to suffer from cognitive financial constraints (i.e. to be in the Lower No need group) if their current ventures are small, less intensive in debt structure, have a low rate of revenue growth in the previous year, and do not actively engage in e-business activities such as having company websites and purchasing products online.

Finally, at the regional level, the odds ratios associated with the South dummy variable are greater than 1 and statistically significant in columns 2,3 , and 5 , indicating that firms in the south of Vietnam are more likely to borrow bank loans. Also, firms located in regions with higher levels of provincial construction and lower level of provincial consumption are more likely to borrow from banks. However, the odds ratios associated with cumulative FDI and SOE capital are all smaller than 1 and statistically significant in all columns, indicating that firms are less likely to take out bank loans in regions that have an active state- or foreign-owned sector. The odds ratios associated with local governance quality are greater than 1 and statistically significant in columns 2,3 , and 5 , indicating that firms in provinces with more efficient governance systems are more likely to borrow from banks.

In general, at the regional level, we find that entrepreneurs whose businesses are located in regions in the north of Vietnam (therefore follow the purely socialist blueprint), or regions with a higher concentration of foreign- or state-owned firms, or regions with a lower level of public spending on local infrastructure, or a poorer quality of local governance are more likely to suffer from cognitive financial constraints (i.e. to be in the Lower No need group).

To sum up, these findings are consistent with the literature and indicate that factors at individual level, organisational level, and contextual level are all essential to the creation of cognitive financial constraints.

\subsection{Cognitive financial constraints and firm performance}

Moving on to the firm performance model, Table 4 presents the regression results. Revenue growth results are presented in columns 1-4 and asset growth results in columns 5-8. All specification tests indicate that there are no serious econometric problems with the modelling. Specifically, the Hansen (J) $p$-value is insignificant, indicating the validity of the instrumental variables. Furthermore, the Sanderson-Windmeijer (SW) first-stage tests of underidentification and weak identification show that endogenous regressors in question are not unidentified. This is also confirmed by Kleibergen-Paap LM statistics. Moreover, Anderson-Rubin tests and Stock-Wright LM S statistics indicate that the overidentifying restrictions are basically valid in most specifications. 
Table 4 Cognitive financial constraints and growth (modified control function)

\begin{tabular}{|c|c|c|c|c|c|c|c|c|}
\hline & $\begin{array}{l}(1) \\
\text { Revenue } \\
\text { growth }\end{array}$ & $\begin{array}{l}(2) \\
\text { Revenue } \\
\text { growth }\end{array}$ & $\begin{array}{l}(3) \\
\text { Revenue } \\
\text { growth }\end{array}$ & $\begin{array}{l}(4) \\
\text { Revenue } \\
\text { growth }\end{array}$ & $\begin{array}{l}\text { (5) } \\
\text { Asset } \\
\text { growth }\end{array}$ & $\begin{array}{l}\text { (6) } \\
\text { Asset } \\
\text { growth }\end{array}$ & $\begin{array}{l}\text { (7) } \\
\text { Asset } \\
\text { growth }\end{array}$ & $\begin{array}{l}\text { (8) } \\
\text { Asset growth }\end{array}$ \\
\hline Intention & $\begin{array}{l}\mathbf{0 . 0 4 5} * * * \\
(0.017)\end{array}$ & & & $\begin{array}{l}\mathbf{0 . 0 5 5} * * * \\
(0.017)\end{array}$ & $\begin{array}{l}\mathbf{0 . 0 8 3} * * * \\
(0.013)\end{array}$ & & & $\begin{array}{l}\text { 0.071 *** } \\
(0.013)\end{array}$ \\
\hline Dissatisfied & & $\begin{array}{l}\mathbf{0 . 0 4 0} * * * \\
(0.011)\end{array}$ & & $\begin{array}{l}\mathbf{0 . 0 3 8} * * * \\
(0.011)\end{array}$ & & $\begin{array}{l}\mathbf{0 . 1 1 9} * * * \\
(0.010)\end{array}$ & & $\begin{array}{l}\mathbf{0 . 1 1 5} * * * \\
(0.009)\end{array}$ \\
\hline Satisfied & & & $\begin{array}{l}\mathbf{0 . 0 4 1} * * * \\
(0.012)\end{array}$ & $\begin{array}{l}\mathbf{0 . 0 4 0} * * * \\
(0.012)\end{array}$ & & & $\begin{array}{l}\mathbf{0 . 1 2 2} * * * \\
(0.009)\end{array}$ & $0.121 * * *$ \\
\hline Owner age & $\begin{array}{l}-0.003 * * * \\
(0.001)\end{array}$ & $\begin{array}{l}-0.004 * * * \\
(0.001)\end{array}$ & $\begin{array}{l}-0.004 * * * \\
(0.001)\end{array}$ & $\begin{array}{l}-0.004 * * * \\
(0.000)\end{array}$ & $\begin{array}{l}0.002 * * * \\
(0.001)\end{array}$ & $\begin{array}{l}-0.000 \\
(0.000)\end{array}$ & $\begin{array}{l}-0.001 \\
(0.000)\end{array}$ & $\begin{array}{l}-0.001^{*} \\
(0.000)\end{array}$ \\
\hline $\begin{array}{l}\text { Owner } \\
\text { gender }\end{array}$ & $\begin{array}{l}0.032 * \\
(0.018)\end{array}$ & $\begin{array}{l}0.003 \\
(0.014)\end{array}$ & $\begin{array}{l}0.011 \\
(0.011)\end{array}$ & $\begin{array}{l}0.004 \\
(0.009)\end{array}$ & $\begin{array}{l}0.011 \\
(0.015)\end{array}$ & $\begin{array}{l}0.010 \\
(0.011)\end{array}$ & $\begin{array}{l}0.006 \\
(0.009)\end{array}$ & $\begin{array}{l}0.004 \\
(0.007)\end{array}$ \\
\hline Firm age & $\begin{array}{l}-0.015 * * * \\
(0.001)\end{array}$ & $\begin{array}{l}-0.017 * * * \\
(0.001)\end{array}$ & $\begin{array}{l}-0.013 * * * \\
(0.001)\end{array}$ & $\begin{array}{l}-0.016^{* * * *} \\
(0.001)\end{array}$ & $\begin{array}{l}-0.004 * * * \\
(0.001)\end{array}$ & $\begin{array}{l}-0.006^{* * * *} \\
(0.001)\end{array}$ & $\begin{array}{l}-0.005^{* * * *} \\
(0.001)\end{array}$ & $\begin{array}{l}-0.006 * * * \\
(0.001)\end{array}$ \\
\hline Firm size & $\begin{array}{l}0.061 * * * \\
(0.008)\end{array}$ & $\begin{array}{l}0.049 * * * \\
(0.006)\end{array}$ & $\begin{array}{l}0.027 * * * \\
(0.005)\end{array}$ & $\begin{array}{l}0.040 * * * \\
(0.004)\end{array}$ & $\begin{array}{l}0.104 * * * \\
(0.007)\end{array}$ & $\begin{array}{l}0.063 * * * \\
(0.005)\end{array}$ & $\begin{array}{l}0.047 * * * \\
(0.004)\end{array}$ & $\begin{array}{l}0.047 * * * \\
(0.003)\end{array}$ \\
\hline Profitability & $\begin{array}{l}0.935 * * * \\
(0.082)\end{array}$ & $\begin{array}{l}1.185 * * * \\
(0.073)\end{array}$ & $\begin{array}{l}1.053 * * * \\
(0.059)\end{array}$ & $\begin{array}{l}1.124 * * * \\
(0.051)\end{array}$ & $\begin{array}{l}0.450 * * * \\
(0.076)\end{array}$ & $\begin{array}{l}0.470 * * * \\
(0.063)\end{array}$ & $\begin{array}{l}0.314 * * * \\
(0.052)\end{array}$ & $\begin{array}{l}0.386 * * * \\
(0.044)\end{array}$ \\
\hline $\begin{array}{l}\text { Asset struc- } \\
\text { ture }\end{array}$ & $\begin{array}{l}-0.089 * * * \\
(0.035)\end{array}$ & $\begin{array}{l}-0.081 * * * \\
(0.025)\end{array}$ & $\begin{array}{l}-0.064 * * * \\
(0.022)\end{array}$ & $\begin{array}{l}-0.079 * * * \\
(0.017)\end{array}$ & $\begin{array}{l}-0.129 * * * \\
(0.028)\end{array}$ & $\begin{array}{l}-0.181 * * * \\
(0.019)\end{array}$ & $\begin{array}{l}-0.196 * * * \\
(0.016)\end{array}$ & $\begin{array}{l}-0.212 * * * \\
(0.013)\end{array}$ \\
\hline $\begin{array}{l}\text { Debt struc- } \\
\text { ture }\end{array}$ & $\begin{array}{l}0.170 * * * \\
(0.028)\end{array}$ & $\begin{array}{l}0.203 * * * \\
(0.022)\end{array}$ & $\begin{array}{l}0.179 * * * \\
(0.019)\end{array}$ & $\begin{array}{l}0.195 * * * \\
(0.016)\end{array}$ & $\begin{array}{l}0.310 * * * \\
(0.024)\end{array}$ & $\begin{array}{l}0.328 * * * \\
(0.018)\end{array}$ & $\begin{array}{l}0.329 * * * \\
(0.016)\end{array}$ & $\begin{array}{l}0.336 * * * \\
(0.012)\end{array}$ \\
\hline Investment & $\begin{array}{l}0.115 * * \\
(0.046)\end{array}$ & $\begin{array}{l}0.244 * * * \\
(0.035)\end{array}$ & $\begin{array}{l}0.225 * * * \\
(0.032)\end{array}$ & $\begin{array}{l}0.246 * * * \\
(0.025)\end{array}$ & $\begin{array}{l}0.406 * * * \\
(0.049)\end{array}$ & $\begin{array}{l}0.547 * * * \\
(0.034)\end{array}$ & $\begin{array}{l}0.512 * * * \\
(0.028)\end{array}$ & $\begin{array}{l}0.591 * * * \\
(0.022)\end{array}$ \\
\hline $\begin{array}{l}\text { Provincial } \\
\text { construc- } \\
\text { tions }\end{array}$ & $\begin{array}{l}0.011 * * \\
(0.004)\end{array}$ & $\begin{array}{l}0.005 * \\
(0.003)\end{array}$ & $\begin{array}{l}0.005 * \\
(0.003)\end{array}$ & $\begin{array}{l}0.007 * * * \\
(0.002)\end{array}$ & $\begin{array}{l}-0.008 * * \\
(0.003)\end{array}$ & $\begin{array}{l}-0.006 * * * \\
(0.002)\end{array}$ & $\begin{array}{l}-0.004 * * \\
(0.002)\end{array}$ & $\begin{array}{l}-0.005^{* * * *} \\
(0.001)\end{array}$ \\
\hline $\begin{array}{l}\text { Provincial } \\
\text { consump- } \\
\text { tions }\end{array}$ & $\begin{array}{l}-0.003 * * * \\
(0.001)\end{array}$ & $\begin{array}{l}-0.002 * * \\
(0.001)\end{array}$ & $\begin{array}{l}-0.002 * * * \\
(0.001)\end{array}$ & $\begin{array}{l}-0.002 * * * \\
(0.000)\end{array}$ & $\begin{array}{l}-0.007 * * * \\
(0.001)\end{array}$ & $\begin{array}{l}-0.007 * * * \\
(0.001)\end{array}$ & $\begin{array}{l}-0.006^{* * * *} \\
(0.000)\end{array}$ & $\begin{array}{l}-0.007 * * * \\
(0.000)\end{array}$ \\
\hline Distance & $\begin{array}{l}0.027 \\
(0.094)\end{array}$ & $\begin{array}{l}-0.008 \\
(0.062)\end{array}$ & $\begin{array}{l}-0.015 \\
(0.050)\end{array}$ & $\begin{array}{l}-0.006 \\
(0.041)\end{array}$ & $\begin{array}{l}0.149 * * \\
(0.059)\end{array}$ & $\begin{array}{l}0.043 \\
(0.038)\end{array}$ & $\begin{array}{l}0.056 * \\
(0.032)\end{array}$ & $\begin{array}{l}0.034 \\
(0.025)\end{array}$ \\
\hline $\begin{array}{l}\text { Cumulative } \\
\text { FDI }\end{array}$ & $\begin{array}{l}-0.026 \\
(0.016)\end{array}$ & $\begin{array}{l}-0.013 \\
(0.013)\end{array}$ & $\begin{array}{l}-0.016 \\
(0.010)\end{array}$ & $\begin{array}{l}-0.014 \\
(0.009)\end{array}$ & $\begin{array}{l}-0.009 \\
(0.013)\end{array}$ & $\begin{array}{l}-0.017^{*} \\
(0.010)\end{array}$ & $\begin{array}{l}-0.020^{* *} \\
(0.008)\end{array}$ & $\begin{array}{l}-0.026 * * * \\
(0.007)\end{array}$ \\
\hline SOE capital & $\begin{array}{l}-0.190 \\
(0.120)\end{array}$ & $\begin{array}{l}-0.112 \\
(0.089)\end{array}$ & $\begin{array}{l}-0.099 \\
(0.079)\end{array}$ & $\begin{array}{l}-0.152 * * \\
(0.062)\end{array}$ & $\begin{array}{l}0.231 * * * \\
(0.085)\end{array}$ & $\begin{array}{l}0.272 * * * \\
(0.059)\end{array}$ & $\begin{array}{l}0.181 * * * \\
(0.055)\end{array}$ & $\begin{array}{l}0.220 * * * \\
(0.041)\end{array}$ \\
\hline $\begin{array}{l}\text { Local } \\
\text { governance } \\
\text { quality }\end{array}$ & $\begin{array}{l}-0.001 \\
(0.002)\end{array}$ & $\begin{array}{l}-0.004 * * \\
(0.002)\end{array}$ & $\begin{array}{l}-0.002^{*} \\
(0.001)\end{array}$ & $\begin{array}{l}-0.003 * * * \\
(0.001)\end{array}$ & $\begin{array}{l}0.004 * * * \\
(0.001)\end{array}$ & $\begin{array}{l}0.005 * * * \\
(0.001)\end{array}$ & $\begin{array}{l}0.005 * * * \\
(0.001)\end{array}$ & $\begin{array}{l}0.005 * * * \\
(0.001)\end{array}$ \\
\hline VIF & 2.512 & 2.354 & 2.884 & 3.102 & 2.512 & 2.441 & 2.058 & 3.021 \\
\hline Hansen $(J)$ & 0.147 & 0.065 & 0.027 & 0.186 & 0.124 & 0.055 & 0.623 & 0.417 \\
\hline $\begin{array}{l}\text { Stock-Wright } \\
\text { LM } S\end{array}$ & 0.142 & 0.066 & 0.000 & 0.000 & 0.097 & 0.018 & 0.029 & 0.000 \\
\hline $\begin{array}{l}\text { Anderson- } \\
\text { Rubin }\end{array}$ & 0.184 & 0.079 & 0.000 & 0.000 & 0.125 & 0.024 & 0.036 & 0.000 \\
\hline $\begin{array}{l}\text { Kleibergen- } \\
\text { Paap }\end{array}$ & 0.000 & 0.000 & 0.000 & 0.000 & 0.000 & 0.000 & 0.000 & 0.000 \\
\hline
\end{tabular}


Table 4 (continued)

\begin{tabular}{|c|c|c|c|c|c|c|c|c|}
\hline & (1) & (2) & (3) & (4) & (5) & (6) & (7) & (8) \\
\hline & $\begin{array}{l}\text { Revenue } \\
\text { growth }\end{array}$ & $\begin{array}{l}\text { Revenue } \\
\text { growth }\end{array}$ & $\begin{array}{l}\text { Revenue } \\
\text { growth }\end{array}$ & $\begin{array}{l}\text { Revenue } \\
\text { growth }\end{array}$ & $\begin{array}{l}\text { Asset } \\
\text { growth }\end{array}$ & $\begin{array}{l}\text { Asset } \\
\text { growth }\end{array}$ & $\begin{array}{l}\text { Asset } \\
\text { growth }\end{array}$ & Asset growth \\
\hline $\begin{array}{l}\text { Sanderson- } \\
\text { Windmei- } \\
\text { jer }\end{array}$ & 0.000 & 0.000 & 0.000 & 0.000 & 0.000 & 0.000 & 0.000 & 0.000 \\
\hline Observations & 204,135 & 204,135 & 204,135 & 204,135 & 204,135 & 204,135 & 204,135 & 204,135 \\
\hline$R$-squared & 0.036 & 0.032 & 0.034 & 0.043 & 0.120 & 0.121 & 0.119 & 0.126 \\
\hline
\end{tabular}

The dependent variable in columns 1-4 is revenue growth. The dependent variable in columns 5-8 is asset growth. The benchmark is Lower No need group. All specifications are results estimated employing Wooldridge's (2015) modified control function. All estimations include full sets of two-digit industry dummies, 63 province dummies, and 8 dummies for owner education. Hansen $(J)$ is a test of overidentifying restrictions; the joint null hypothesis is that the instruments are valid instruments. Sanderson-Windmeijer (SW) is the test for underidentification and weak identification. The null that the particular endogenous regressors in question is unidentified. Kleibergen-Paap is a test of matrix rank. The null that the matrix of reduced form coefficients has rank $=K 1$. Anderson-Rubin and Stock-Wright LM $S$ are tests of overidentifying restrictions. The null that the coefficients of the endogenous regressors in the structural equation are jointly equal to zero. The figures reported in parentheses are heteroskedasticity robust standard errors, clustered by province. $* * *$ Significant at $1 \% ; * *$ Significant at $5 \%$; * Significant at $10 \%$

The coefficients associated with the Satisfied, Dissatisfied, and Intention variables are positive and statistically significant in all specifications. This finding indicates that firms that are borrowing, irrespective of whether they are satisfied or dissatisfied with their bank loans, and firms that are not borrowing but intend to do so perform (in terms of growth rates) better than firms that do not want to borrow (Lower No need group). Therefore, hypotheses $\mathrm{H} 1, \mathrm{H} 2$, and $\mathrm{H} 3$ are fully supported. On average, firms that take out loans with which they are satisfied achieve 4.0\% more revenue growth and $12.1 \%$ more asset growth compared to firms that do not want to take out loans (columns 4 and 8, Table 4). Meanwhile, firms that take out loans, even when they are dissatisfied with the amounts borrowed, also achieve 3.8\% more revenue growth and $11.5 \%$ more asset growth than firms that do not want to take out loans (columns 4 and 8 , Table 4).

To measure the effects of financial constraints, we look at the difference between the Satisfied and Dissatisfied groups: the difference between the two treatments for revenue growth is $0.2 \%(4.0-3.8 \%)$, and $0.6 \%$ for asset growth (12.1-11.5\%), indicating that obtaining insufficient finance holds back financially constrained firms by $0.2 \%$ of revenue growth and $0.6 \%$ of asset growth on average. However, the Wald test confirms that the coefficients associated with
Satisfied and Dissatisfied are not statistically significantly different, even at $10 \%$ significance level.

We also find that firms that do not want to borrow achieve $5.5 \%$ less revenue growth and $7.1 \%$ less asset growth than the firms that have the intention to borrow but have not yet applied for bank loans (i.e. the coefficients associated with the Intention variable). This finding thus confirms hypothesis $\mathrm{H} 4$.

In short, regression results in Table 44 confirm that cognitive financial constraints are an essential obstacle to firm growth. It is evidently shown that entrepreneurs that have an intention to borrow, even if they have not successfully obtained bank loans, can boost their ventures' growth rates significantly. Financing constraints, at least in the context of Vietnam, are less of an impediment to firm growth since the results show that the growth rates of firms satisfied with bank loans do not significantly differ from those of firms unsatisfied with bank loans.

Regarding the control variables, there are some interesting patterns. At the individual level, firms run by young entrepreneurs outperform firms run by old entrepreneurs. This is evidenced by the negative coefficients associated with owner age variable. In general, when entrepreneurs are one year older, their venture growth rate will reduce by $0.3 \%$, holding all else constant. This finding is consistent with the strand of literature arguing that young entrepreneurs are more 
willing to take risks and pursue high-growth industries (e.g., hi-tech) (Turner \& Nguyen, 2005).

At the firm level, labour size, profitability, investments, and debts appear to be positively associated with growth rates. This finding is consistent with organisation management literature, which argues that resources are an important precedent of growth rates (Baker \& Nelson, 2005). Profitability appears to have the strongest effect on growth rate (1.12\% growth rates per $1 \%$ increase in profit-column 4, Table 4). Meanwhile, the effects of debts, investments, and firm size are $0.20 \%, 0.25 \%$, and $0.04 \%$, respectively (column 4 , Table 4 ). However, it is noteworthy that firm age and asset structure are negatively associated with growth. This could be explained by the fact that older firms may lack entrepreneurial orientation (Zucchella et al., 2007) and that an excessively high level of fixed assets may harm productivity (Brown et al., 2018).

Finally, the effects of provincial variables on revenue growth and asset growth are not consistent, probably because entrepreneurs respond differently to their external environments when it comes to deciding whether to focus on maximising revenue incomes or expansion (asset growth). However, provincial consumption power is consistently negatively associated with both revenue and asset growth. This counter-intuitive finding may be explained by the fact that regions that have stronger consumption powers also attract more business ventures, thereby boosting competition and limiting growth rates.

We also conduct robustness tests using full observations of the No need group, multi-level modelling, and matching technique. For the matching technique, we employ both the conventional propensity score matching (PSM) and the more advanced coarsened exact matching (CEM) for the sake of robustness. The discussions and results are reported in Appendix 2.

\section{Discussion and conclusion}

In this study, we examine two types of financial barriers to firm growth-financial supply constraints and cognitive financial constraints. The extant literature does not provide sufficient understanding of their similarities and differences. Both are observed as funding gaps as they limit the potential for firm development. However, financial constraints arise from market failures, and originate from the supply side of the financial markets; cognitive financial constraints, on the other hand, are a problem stemming from entrepreneurs' biased perceptions, and originate from the demand side of the financial markets. Although both exert a negative impact on firm growth, they differ in nature.

The conceptualisation and accompanied empirical evidence in this study are intended to make two important contributions to the literature. First, it conceptually distinguishes cognitive financial constraints from financial supply constraints. Financial constraints result from the transaction costs that have been conventionally considered to be at the root of the funding gap. However, we contend that entrepreneurs' cognitive financial constraints are also responsible. Entrepreneurs, due to their own biased perceptions, may refuse to consider formal borrowing despite being qualified to apply. Thus, the funding gap may widen because entrepreneurs have passive entrepreneurial styles and exhibit low tolerance for taking risks. These cognitive biases downgrade the entrepreneurial ability to recognise profitable opportunities or to fully utilise their gained experience, education, and ability to interpret reality (Baron, 2007). We use institutional theory to offer an explanation for the establishment of these cognitive biases, highlighting the roles of the prevailing conservative entrepreneurial norms, values, and beliefs in the examined context (Aidis, 2005).

Second, this study provides a conceptual framework in which the importance of cognitive financial constraints to firm growth may be studied and compared with the effects of financial supply constraints on firm growth. When mitigating financial constraints by improving the formal institutional systems (financing rules, laws, and regulations), one also needs to deal with the informal institutions (norms, values, and beliefs), and sometimes even focus on local cultures in order to repair cognitive 
biases. These variables are sticky and difficult to change in the short and medium terms (Williamson, 2000). Therefore, reducing cognitive financial constraints is a time-consuming but long-lasting method of driving growth, which makes it highly impactful.

Moreover, the findings in this study provide several important insights into the literature on financial constraints. According to the conventional definition of financial constraints, firms in the No need and Satisfied groups are classified as being not-so-financially constrained, i.e. they do not require additional capital (Carpenter \& Petersen, 2002). Thus, it can be expected that the not-so-financially constrained firms should perform better than the financially constrained firms (Bond \& Meghir, 1994; Guariglia, 2008). However, the findings in this study show that firms in the Satisfied group perform significantly better than firms in the No Need group even though they are, at least according to the conventional wisdom, equally notso-financially constrained.

This result is not contrary to the theory of financial constraints. Rather, it indicates that the implicit assumption of the financial constraints theory, i.e. that capital demand is always perfect, may fail to exert its validity in some particular contexts (e.g. post-communist entrepreneurship). Fraser et al. (2015) highlight that there is a need to look beyond the traditional supply-side/market failure perspective if we wish to better understand the role that financing cognitions and styles play in financing decisions. We consider the issue from the demand side and find that there are also failures originating from entrepreneurial cognition. Some cognitive patterns are triggered by biased/limited reflections, or are influenced by the surrounding conservative normative forces or institutions that may restrict entrepreneurs' ability and confidence. This study thus serves as an extension of the theoretical discussions of Fraser et al. (2015). Our arguments and findings identify an important topic in which the relative roles of financial supply and cognitive financial constraints need careful investigation.

This study also adds useful contributions to the entrepreneurship literature. We propose a mechanism through which a financing decision that is as yet merely intentional could influence a firm's actual performance. Baron (2007) suggests that cognitive patterns direct entrepreneurs' abilities to identify novel opportunities. Meanwhile, Busenitz et al. (2000) argue that perceptions of skills and entrepreneurial intention and alertness affect certain types of entrepreneurial traits. We go a step further by presenting a bigger picture that connects financing cognitions to firm growth performance.

Findings in this study offer significant implications for entrepreneurs and policymakers. Governments usually devote attention and resources to solving problems with the supply side of the capital markets by, for example, introducing subsidies for small businesses and reducing interest rates for newly established firms. However, these resources will be misallocated or even wasted if the demand side remains stuck because entrepreneurs simply do not want to avail themselves of external borrowing. Unless governments also help to alleviate cognitive financial constraints, their efforts to develop effective financial markets cannot yield an optimal result.

Finally, this study has some limitations that could be addressed in future research. First, it is important to test the impact of cognitive financial constraints on firm performance using mechanisms other than financing. These might include productivity improvements and social responsibility. Moreover, the availability of the data means that this study is a short timeframe analysis. Future studies could expand the proposed theoretical framework and re-test it in other contexts using longitudinal data.

Acknowledgements We are grateful to the Editor and three Reviewers that help us improve the paper significantly. All errors left remain ours.

Funding This research is funded by Vietnam National Foundation for Science and Technology Development (NAFOSTED) under grant number 502.01-2020.01 for Bach Nguyen. Also, Jun Du gratefully acknowledges the financial support of the Leverhulme Trust Research Fellowship under grant number RF-2016-661 and the Lloyds Banking Group Centre for Business Prosperity. 


\section{Appendix 1}

Table 5

Table 5 Pairwise correlation matrix

\begin{tabular}{|c|c|c|c|c|c|c|c|c|c|c|c|c|c|c|c|c|c|c|}
\hline & (1) & (2) & (3) & (4) & (5) & (6) & (7) & (8) & (9) & (10) & (11) & (12) & (13) & (14) & (15) & (16) & (17) & (18) \\
\hline \multicolumn{19}{|l|}{ Revenue growth (1) } \\
\hline Asset growth (2) & 0.08 & & & & & & & & & & & & & & & & & \\
\hline Intention (3) & 0.02 & 0.02 & & & & & & & & & & & & & & & & \\
\hline Dissatisfied (4) & 0.03 & 0.16 & . & & & & & & & & & & & & & & & \\
\hline Satisfied (5) & 0.04 & 0.11 & . & . & & & & & & & & & & & & & & \\
\hline Owner age (6) & -0.05 & 0.01 & 0.00 & 0.05 & 0.07 & & & & & & & & & & & & & \\
\hline Owner gender (7) & 0.08 & -0.05 & 0.01 & 0.05 & 0.02 & 0.11 & & & & & & & & & & & & \\
\hline Firm age (8) & -0.08 & -0.09 & 0.01 & 0.00 & 0.01 & 0.32 & 0.05 & & & & & & & & & & & \\
\hline Firm size (9) & 0.06 & 0.07 & 0.05 & 0.11 & 0.12 & 0.17 & 0.12 & 0.19 & & & & & & & & & & \\
\hline Profitability (10) & 0.07 & 0.06 & -0.02 & 0.00 & 0.04 & 0.07 & 0.01 & 0.08 & 0.06 & & & & & & & & & \\
\hline Asset structure (11) & -0.01 & 0.01 & 0.02 & 0.13 & 0.14 & 0.19 & 0.04 & 0.05 & 0.12 & 0.02 & & & & & & & & \\
\hline Debt structure (12) & 0.02 & 0.14 & 0.08 & 0.20 & 0.23 & 0.02 & -0.04 & 0.07 & 0.17 & -0.17 & -0.11 & & & & & & & \\
\hline Investment (13) & 0.04 & 0.09 & -0.02 & -0.07 & -0.08 & -0.13 & -0.01 & -0.21 & -0.14 & -0.11 & 0.12 & -0.28 & & & & & & \\
\hline Constructions (14) & 0.00 & -0.09 & 0.02 & -0.13 & -0.18 & -0.18 & -0.11 & 0.04 & -0.07 & -0.10 & -0.26 & 0.12 & -0.08 & & & & & \\
\hline Consumptions (15) & 0.01 & -0.12 & -0.02 & -0.23 & -0.24 & -0.17 & -0.12 & 0.05 & -0.06 & -0.07 & -0.29 & 0.08 & -0.11 & 0.76 & & & & \\
\hline Distance (16) & 0.00 & 0.08 & 0.00 & 0.17 & 0.19 & 0.13 & 0.11 & 0.01 & 0.01 & 0.08 & 0.20 & -0.08 & 0.06 & -0.59 & -0.58 & & & \\
\hline Cumulative FDI (17) & 0.00 & -0.06 & -0.03 & -0.19 & -0.18 & -0.09 & -0.07 & -0.05 & 0.06 & -0.07 & -0.15 & 0.07 & -0.04 & 0.29 & 0.39 & -0.58 & & \\
\hline SOE capital (18) & -0.04 & 0.03 & 0.02 & -0.03 & -0.07 & -0.10 & -0.14 & 0.01 & -0.05 & -0.05 & -0.13 & 0.09 & -0.04 & 0.73 & 0.29 & -0.38 & 0.09 & \\
\hline Governance (19) & 0.02 & 0.02 & -0.02 & -0.11 & -0.10 & -0.06 & -0.05 & -0.03 & 0.02 & -0.01 & -0.10 & 0.05 & -0.06 & 0.25 & 0.40 & -0.40 & 0.56 & 0.12 \\
\hline
\end{tabular}

All correlation coefficients are significant at $1 \%$

\section{Appendix 2: Robustness test}

Full sample of No need group

In the main text, we employ the Lower No need group as the benchmark for comparison with other groups. In this section, we conduct the analysis of (1) the precedents of cognitive financial constraints and (2) the effects of cognitive financial constraints on firm performance using the full set of observations in the No Need group. The results are consistent with the findings in the main text. Table 6 presents the results of the precedents of cognitive financial constraints, and Table 7 presents the results of the effects of cognitive financial constraints on firm performance. For the sake of interpretation, all statistics reported in Table 6 are the odds ratios.

\section{Multi-level modelling}

The modified control function could eliminate endogeneity but fail to address the multi-level structure of the growth model. The residual in Eq. (1) is actually comprised of two terms: regional residuals and individual firm residuals. As such, we use multi-level modelling to address the unobserved heterogeneity within the context of a cross-region, cross-individual, firm dataset. The multi-level estimator takes into account the fact that some individual firms may have similar characteristics because they are located in the same province. Thus, for the hierarchical structure of the data, individual firms are set on level one, and provinces are set on level two. This setting allows us to control for clustering the observations by province (Estrin et al., 2013). The specification tests in all regressions indicate that the choice of multi-level modelling is justified: the random intercepts are all statistically significant. Table 8 reports the regression results. In general, the main arguments remain robust in that all hypotheses are fully supported.

\section{Matching}

In addition to the regression technique, we also employ the score matching approach to explicitly deal with the selection bias issues in our data. The observations in the control group (No need) may be different from the observations in the treatment groups (the groups of Intention, Dissatisfied, or Satisfied) in terms of factors (such as firm characteristics) other than the treatment effect (the intention/decision to borrow). If the decision to borrow depends on firm characteristics, then a pairwise comparison of the average performance between the No need group and the other three treated groups reflects the combination of the average causal effect and also the effect of selection bias (Abadie \& Imbens, 2011). 
Table 6 Precedents of financing decisions (full observations of No need)

\begin{tabular}{|c|c|c|c|c|c|}
\hline & \multicolumn{3}{|c|}{ Multinomial logit } & \multirow{2}{*}{$\begin{array}{l}\text { Logit } \\
\text { (4) }\end{array}$} & \multirow{2}{*}{$\begin{array}{l}\text { Logit } \\
(5)\end{array}$} \\
\hline & (1) & (2) & (3) & & \\
\hline & Intention & Dissatisfied & Satisfied & No need vs Intention & No need vs the rest \\
\hline Owner age & $\begin{array}{l}1.058 \\
(0.121)\end{array}$ & $\begin{array}{l}1.623 * * * \\
(0.149)\end{array}$ & $\begin{array}{l}1.385 * * * \\
(0.113)\end{array}$ & $\begin{array}{l}1.035 \\
(0.107)\end{array}$ & $\begin{array}{l}1.370 * * * \\
(0.087)\end{array}$ \\
\hline Owner gender & $\begin{array}{l}1.133 * * * \\
(0.043)\end{array}$ & $\begin{array}{l}1.234 * * * \\
(0.035)\end{array}$ & $\begin{array}{l}1.036 \\
(0.027)\end{array}$ & $\begin{array}{l}1.110 * * * \\
(0.041)\end{array}$ & $\begin{array}{l}1.075 * * * \\
(0.023)\end{array}$ \\
\hline Education & $\begin{array}{l}0.977 * * \\
(0.009)\end{array}$ & $\begin{array}{l}1.041 * * * \\
(0.007)\end{array}$ & $\begin{array}{l}1.022 * * * \\
(0.006)\end{array}$ & $\begin{array}{l}0.981 * * \\
(0.008)\end{array}$ & $\begin{array}{l}1.021 * * * \\
(0.005)\end{array}$ \\
\hline Hoa ethnic & $\begin{array}{l}1.276 \\
(0.218)\end{array}$ & $\begin{array}{l}0.915 \\
(0.132)\end{array}$ & $\begin{array}{l}0.977 \\
(0.127)\end{array}$ & $\begin{array}{l}1.269 \\
(0.212)\end{array}$ & $\begin{array}{l}1.031 \\
(0.110)\end{array}$ \\
\hline Minor ethnic & $\begin{array}{l}0.639 \\
(0.220)\end{array}$ & $\begin{array}{l}0.343 * * * \\
(0.118)\end{array}$ & $\begin{array}{l}0.313 * * * \\
(0.092)\end{array}$ & $\begin{array}{l}0.630 * * * \\
(0.042)\end{array}$ & $\begin{array}{l}0.288 * * * \\
(0.013)\end{array}$ \\
\hline Foreign ethnic & $\begin{array}{l}0.940 \\
(0.192)\end{array}$ & $\begin{array}{l}0.944 \\
(0.128)\end{array}$ & $\begin{array}{l}0.929 \\
(0.117)\end{array}$ & $\begin{array}{l}0.965 \\
(0.173)\end{array}$ & $\begin{array}{l}0.953 \\
(0.094)\end{array}$ \\
\hline Debt structure & $\begin{array}{l}2.286 * * * \\
(0.123)\end{array}$ & $\begin{array}{l}6.539 * * * \\
(0.261)\end{array}$ & $\begin{array}{l}7.428 * * * \\
(0.273)\end{array}$ & $\begin{array}{l}2.087 * * * \\
(0.090)\end{array}$ & $\begin{array}{l}5.399 * * * \\
(0.160)\end{array}$ \\
\hline Revenue growth & $\begin{array}{l}1.071 * * * \\
(0.015)\end{array}$ & $\begin{array}{l}1.024 * * \\
(0.011)\end{array}$ & $\begin{array}{l}1.026 * * * \\
(0.010)\end{array}$ & $\begin{array}{l}1.059 * * * \\
(0.012)\end{array}$ & $\begin{array}{l}1.033 * * * \\
(0.008)\end{array}$ \\
\hline Asset structure & $\begin{array}{l}1.496 * * * \\
(0.118)\end{array}$ & $\begin{array}{l}3.129 * * * \\
(0.170)\end{array}$ & $\begin{array}{l}3.496 * * * \\
(0.177)\end{array}$ & $\begin{array}{l}1.371 * * * \\
(0.089)\end{array}$ & $\begin{array}{l}2.346^{* * * *} \\
(0.095)\end{array}$ \\
\hline Firm size & $\begin{array}{l}1.137 * * * \\
(0.022)\end{array}$ & $\begin{array}{l}1.280 * * * \\
(0.018)\end{array}$ & $\begin{array}{l}1.264 * * * \\
(0.017)\end{array}$ & $\begin{array}{l}1.120 * * * \\
(0.019)\end{array}$ & $\begin{array}{l}1.206 * * * \\
(0.013)\end{array}$ \\
\hline South & $\begin{array}{l}1.347 \\
(0.612)\end{array}$ & $\begin{array}{l}12.460 * * * \\
(7.159)\end{array}$ & $\begin{array}{l}7.837 * * * \\
(4.167)\end{array}$ & $\begin{array}{l}1.652 \\
(0.863)\end{array}$ & $\begin{array}{l}4.761 * * * \\
(1.619)\end{array}$ \\
\hline Provincial construction & $\begin{array}{l}1.069 * * * \\
(0.011)\end{array}$ & $\begin{array}{l}1.135 * * * \\
(0.009)\end{array}$ & $\begin{array}{l}1.051 * * * \\
(0.008)\end{array}$ & $\begin{array}{l}1.010 * * \\
(0.005)\end{array}$ & $\begin{array}{l}1.025 * * * \\
(0.003)\end{array}$ \\
\hline Provincial consumption & $\begin{array}{l}0.989 * * * \\
(0.002)\end{array}$ & $\begin{array}{l}0.960 * * * \\
(0.001)\end{array}$ & $\begin{array}{l}0.971 * * * \\
(0.001)\end{array}$ & $\begin{array}{l}1.070 * * * \\
(0.012)\end{array}$ & $\begin{array}{l}1.080 * * * \\
(0.006)\end{array}$ \\
\hline Cumulative FDI & $\begin{array}{l}0.832 * * * \\
(0.026)\end{array}$ & $\begin{array}{l}0.648 * * * \\
(0.015)\end{array}$ & $\begin{array}{l}0.681 * * * \\
(0.014)\end{array}$ & $\begin{array}{l}0.989 * * * \\
(0.002)\end{array}$ & $\begin{array}{l}0.971 * * * \\
(0.001)\end{array}$ \\
\hline SOE capital & $\begin{array}{l}0.128 * * * \\
(0.067)\end{array}$ & $\begin{array}{l}0.058 * * * \\
(0.022)\end{array}$ & $\begin{array}{l}0.249 * * * \\
(0.093)\end{array}$ & $\begin{array}{l}0.859 * * * \\
(0.023)\end{array}$ & $\begin{array}{l}0.710 * * * \\
(0.011)\end{array}$ \\
\hline Local governance quality & $\begin{array}{l}1.010 * \\
(0.005)\end{array}$ & $\begin{array}{l}1.028 * * * \\
(0.003)\end{array}$ & $\begin{array}{l}1.023 * * * \\
(0.003)\end{array}$ & $\begin{array}{l}0.134 * * * \\
(0.074)\end{array}$ & $\begin{array}{l}0.169 * * * \\
(0.050)\end{array}$ \\
\hline VIF & 2.132 & 2.132 & 2.132 & 2.538 & 2.146 \\
\hline$R$-squared & 0.065 & 0.065 & 0.065 & 0.137 & 0.018 \\
\hline Observations & 232,662 & 232,662 & 232,662 & 110,252 & 232,662 \\
\hline
\end{tabular}

The statistics reported in the table are the odds ratios. The dependent variable in columns 1,2 , and 3 is a category variable, which takes value 0 for No need, 1 for Intention, 2 for Dissatisfied, and 3 for Satisfied (No need serves as the benchmark). The dependent variable in columns 4 is a dummy variable, which takes value 0 for No need, and 1 for Intention. The dependent variable in columns 4 is a dummy variable, which takes value 0 for No need, 1 for the other three groups. All estimations include full sets of two-digit industry dummies and 63 province dummies. VIF is a test of variance inflation factor. ***Significant at $1 \%$; **ignificant at $5 \%$; *significant at $10 \%$ 
Table 7 Cognitive financial constraints and growth (full observations of No need)

\begin{tabular}{|c|c|c|c|c|c|c|c|c|}
\hline & $\begin{array}{l}\text { (1) } \\
\text { Revenue } \\
\text { growth }\end{array}$ & $\begin{array}{l}(2) \\
\text { Revenue } \\
\text { growth }\end{array}$ & $\begin{array}{l}(3) \\
\text { Revenue } \\
\text { growth }\end{array}$ & $\begin{array}{l}\text { (4) } \\
\text { Revenue } \\
\text { growth }\end{array}$ & $\begin{array}{l}\text { (5) } \\
\text { Asset } \\
\text { growth }\end{array}$ & $\begin{array}{l}\text { (6) } \\
\text { Asset } \\
\text { growth }\end{array}$ & $\begin{array}{l}\text { (7) } \\
\text { Asset } \\
\text { growth }\end{array}$ & $\begin{array}{l}\text { (8) } \\
\text { Asset growth }\end{array}$ \\
\hline Intention & $\begin{array}{l}\mathbf{0 . 0 3 9} * * \\
(0.017)\end{array}$ & & & $\begin{array}{l}\mathbf{0 . 0 4 5} * * * \\
(0.017)\end{array}$ & $\begin{array}{l}\mathbf{0 . 0 2 3} * \\
(0.013)\end{array}$ & & & $\begin{array}{l}\mathbf{0 . 0 2 6} * * \\
(0.013)\end{array}$ \\
\hline Dissatisfied & & $\begin{array}{l}\mathbf{0 . 0 2 7} * * \\
(0.012)\end{array}$ & & $\begin{array}{l}\mathbf{0 . 0 2 8} * * \\
(0.011)\end{array}$ & & $\begin{array}{l}\mathbf{0 . 0 6 8} * * * \\
(0.009)\end{array}$ & & $\begin{array}{l}\mathbf{0 . 0 6 9} * * * \\
(0.008)\end{array}$ \\
\hline Satisfied & & & $\begin{array}{l}\mathbf{0 . 0 2 7} * * * \\
(0.010)\end{array}$ & $\begin{array}{l}\text { 0.026*** } \\
(0.010)\end{array}$ & & & $\begin{array}{l}\mathbf{0 . 0 7 6} * * * \\
(0.008)\end{array}$ & $\begin{array}{l}\mathbf{0 . 0 7 5} * * * \\
(0.008)\end{array}$ \\
\hline Owner age & $\begin{array}{l}-0.004 * * * \\
(0.001)\end{array}$ & $\begin{array}{l}-0.004 * * * \\
(0.001)\end{array}$ & $\begin{array}{l}-0.004 * * * \\
(0.001)\end{array}$ & $\begin{array}{l}-0.004 * * * \\
(0.000)\end{array}$ & $\begin{array}{l}0.001 \\
(0.001)\end{array}$ & $\begin{array}{l}-0.000 \\
(0.000)\end{array}$ & $\begin{array}{l}-0.001 * * \\
(0.000)\end{array}$ & $\begin{array}{l}-0.001 * * \\
(0.000)\end{array}$ \\
\hline $\begin{array}{l}\text { Owner } \\
\text { gender }\end{array}$ & $\begin{array}{l}0.031 * \\
(0.017)\end{array}$ & $\begin{array}{l}0.009 \\
(0.013)\end{array}$ & $\begin{array}{l}0.014 \\
(0.011)\end{array}$ & $\begin{array}{l}0.007 \\
(0.009)\end{array}$ & $\begin{array}{l}-0.006 \\
(0.014)\end{array}$ & $\begin{array}{l}-0.001 \\
(0.010)\end{array}$ & $\begin{array}{l}-0.002 \\
(0.009)\end{array}$ & $\begin{array}{l}-0.001 \\
(0.007)\end{array}$ \\
\hline Firm age & $\begin{array}{l}-0.017 * * * \\
(0.001)\end{array}$ & $\begin{array}{l}-0.018 * * * \\
(0.001)\end{array}$ & $\begin{array}{l}-0.014 * * * \\
(0.001)\end{array}$ & $\begin{array}{l}-0.016 * * * \\
(0.001)\end{array}$ & $\begin{array}{l}-0.004 * * * \\
(0.001)\end{array}$ & $\begin{array}{l}-0.006 * * * \\
(0.001)\end{array}$ & $\begin{array}{l}-0.005^{* * *} \\
(0.001)\end{array}$ & $\begin{array}{l}-0.006 * * * \\
(0.001)\end{array}$ \\
\hline Firm size & $\begin{array}{l}0.065 * * * \\
(0.008)\end{array}$ & $\begin{array}{l}0.053 * * * \\
(0.006)\end{array}$ & $\begin{array}{l}0.033 * * * \\
(0.005)\end{array}$ & $\begin{array}{l}0.043 * * * \\
(0.004)\end{array}$ & $\begin{array}{l}0.094 * * * \\
(0.006)\end{array}$ & $\begin{array}{l}0.062 * * * \\
(0.005)\end{array}$ & $\begin{array}{l}0.049 * * * \\
(0.004)\end{array}$ & $\begin{array}{l}0.048 * * * \\
(0.003)\end{array}$ \\
\hline Profitability & $\begin{array}{l}0.988 * * * \\
(0.079)\end{array}$ & $\begin{array}{l}1.170 * * * \\
(0.071)\end{array}$ & $\begin{array}{l}1.057 * * * \\
(0.059)\end{array}$ & $\begin{array}{l}1.119 * * * \\
(0.051)\end{array}$ & $\begin{array}{l}0.405 * * * \\
(0.066)\end{array}$ & $\begin{array}{l}0.456 * * * \\
(0.057)\end{array}$ & $\begin{array}{l}0.332 * * * \\
(0.049)\end{array}$ & $\begin{array}{l}0.393 * * * \\
(0.042)\end{array}$ \\
\hline $\begin{array}{l}\text { Asset struc- } \\
\text { ture }\end{array}$ & $\begin{array}{l}-0.028 \\
(0.032)\end{array}$ & $\begin{array}{l}-0.049 * * \\
(0.024)\end{array}$ & $\begin{array}{l}-0.039 * \\
(0.021)\end{array}$ & $\begin{array}{l}-0.062 * * * \\
(0.017)\end{array}$ & $\begin{array}{l}-0.200 * * * \\
(0.024)\end{array}$ & $\begin{array}{l}-0.209 * * * \\
(0.018)\end{array}$ & $\begin{array}{l}-0.218 * * * \\
(0.015)\end{array}$ & $\begin{array}{l}-0.223 * * * \\
(0.012)\end{array}$ \\
\hline $\begin{array}{l}\text { Debt struc- } \\
\text { ture }\end{array}$ & $\begin{array}{l}0.181 * * * \\
(0.025)\end{array}$ & $\begin{array}{l}0.204 * * * \\
(0.021)\end{array}$ & $\begin{array}{l}0.186 * * * \\
(0.019)\end{array}$ & $\begin{array}{l}0.197 * * * \\
(0.015)\end{array}$ & $\begin{array}{l}0.295 * * * \\
(0.020)\end{array}$ & $\begin{array}{l}0.315 * * * \\
(0.016)\end{array}$ & $\begin{array}{l}0.317 * * * \\
(0.015)\end{array}$ & $\begin{array}{l}0.329 * * * \\
(0.012)\end{array}$ \\
\hline Investment & $\begin{array}{l}0.132 * * * \\
(0.041)\end{array}$ & $\begin{array}{l}0.225 * * * \\
(0.033)\end{array}$ & $\begin{array}{l}0.212 * * * \\
(0.030)\end{array}$ & $\begin{array}{l}0.235 * * * \\
(0.024)\end{array}$ & $\begin{array}{l}0.510 * * * \\
(0.039)\end{array}$ & $\begin{array}{l}0.577 * * * \\
(0.030)\end{array}$ & $\begin{array}{l}0.543 * * * \\
(0.026)\end{array}$ & $\begin{array}{l}0.601 * * * \\
(0.021)\end{array}$ \\
\hline $\begin{array}{l}\text { Provincial } \\
\text { construc- } \\
\text { tions }\end{array}$ & $\begin{array}{l}0.010 * * \\
(0.004)\end{array}$ & $\begin{array}{l}0.006 * * \\
(0.003)\end{array}$ & $\begin{array}{l}0.006 * * \\
(0.003)\end{array}$ & $\begin{array}{l}0.007 * * * \\
(0.002)\end{array}$ & $\begin{array}{l}-0.009 * * * \\
(0.003)\end{array}$ & $\begin{array}{l}-0.007 * * * \\
(0.002)\end{array}$ & $\begin{array}{l}-0.005^{* * * *} \\
(0.002)\end{array}$ & $\begin{array}{l}-0.005^{* * * *} \\
(0.001)\end{array}$ \\
\hline $\begin{array}{l}\text { Provincial } \\
\text { consump- } \\
\text { tions }\end{array}$ & $\begin{array}{l}-0.003 * * * \\
(0.001)\end{array}$ & $\begin{array}{l}-0.002^{* * * *} \\
(0.001)\end{array}$ & $\begin{array}{l}-0.002 * * * \\
(0.001)\end{array}$ & $\begin{array}{l}-0.002^{* * * *} \\
(0.000)\end{array}$ & $\begin{array}{l}-0.008 * * * \\
(0.001)\end{array}$ & $\begin{array}{l}-0.007 * * * \\
(0.001)\end{array}$ & $\begin{array}{l}-0.007 * * * \\
(0.000)\end{array}$ & $\begin{array}{l}-0.007 * * * \\
(0.000)\end{array}$ \\
\hline Distance & $\begin{array}{l}0.091 \\
(0.087)\end{array}$ & $\begin{array}{l}0.030 \\
(0.059)\end{array}$ & $\begin{array}{l}0.014 \\
(0.049)\end{array}$ & $\begin{array}{l}0.013 \\
(0.040)\end{array}$ & $\begin{array}{l}0.060 \\
(0.052)\end{array}$ & $\begin{array}{l}0.017 \\
(0.036)\end{array}$ & $\begin{array}{l}0.037 \\
(0.031)\end{array}$ & $\begin{array}{l}0.024 \\
(0.025)\end{array}$ \\
\hline $\begin{array}{l}\text { Cumulative } \\
\text { FDI }\end{array}$ & $\begin{array}{l}0.004 \\
(0.015)\end{array}$ & $\begin{array}{l}0.002 \\
(0.012)\end{array}$ & $\begin{array}{l}-0.005 \\
(0.010)\end{array}$ & $\begin{array}{l}-0.006 \\
(0.009)\end{array}$ & $\begin{array}{l}-0.016 \\
(0.011)\end{array}$ & $\begin{array}{l}-0.019 * * \\
(0.009)\end{array}$ & $\begin{array}{l}-0.019 * * \\
(0.008)\end{array}$ & $\begin{array}{l}-0.025^{* * * *} \\
(0.006)\end{array}$ \\
\hline SOE capital & $\begin{array}{l}-0.159 \\
(0.113)\end{array}$ & $\begin{array}{l}-0.106 \\
(0.086)\end{array}$ & $\begin{array}{l}-0.090 \\
(0.077)\end{array}$ & $\begin{array}{l}-0.141^{* *} \\
(0.061)\end{array}$ & $\begin{array}{l}0.221 * * * \\
(0.075)\end{array}$ & $\begin{array}{l}0.263 * * * \\
(0.055)\end{array}$ & $\begin{array}{l}0.188 * * * \\
(0.052)\end{array}$ & $\begin{array}{l}0.219 * * * \\
(0.040)\end{array}$ \\
\hline $\begin{array}{l}\text { Local } \\
\text { governance } \\
\text { quality }\end{array}$ & $\begin{array}{l}-0.005^{* *} \\
(0.002)\end{array}$ & $\begin{array}{l}-0.005^{* * *} \\
(0.001)\end{array}$ & $\begin{array}{l}-0.004 * * * \\
(0.001)\end{array}$ & $\begin{array}{l}-0.004 * * * \\
(0.001)\end{array}$ & $\begin{array}{l}0.004 * * * \\
(0.001)\end{array}$ & $\begin{array}{l}0.005 * * * \\
(0.001)\end{array}$ & $\begin{array}{l}0.005 * * * \\
(0.001)\end{array}$ & $\begin{array}{l}0.005 * * * \\
(0.001)\end{array}$ \\
\hline VIF & 2.562 & 2.221 & 2.369 & 2.652 & 2.247 & 2.894 & 2.417 & 2.851 \\
\hline Hansen $(J)$ & 0.008 & 0.039 & 0.041 & 0.025 & 0.19 & 0.726 & 0.615 & 0.374 \\
\hline $\begin{array}{l}\text { Stock-Wright } \\
\text { LM S }\end{array}$ & 0.128 & 0.081 & 0.059 & 0.000 & 0.000 & 0.041 & 0.026 & 0.000 \\
\hline $\begin{array}{l}\text { Anderson- } \\
\text { Rubin }\end{array}$ & 0.974 & 0.063 & 0.045 & 0.000 & 0.000 & 0.028 & 0.014 & 0.000 \\
\hline $\begin{array}{l}\text { Kleibergen- } \\
\text { Paap }\end{array}$ & 0.000 & 0.000 & 0.000 & 0.000 & 0.000 & 0.000 & 0.000 & 0.000 \\
\hline
\end{tabular}


Table 7 (continued)

\begin{tabular}{|c|c|c|c|c|c|c|c|c|}
\hline & (1) & (2) & (3) & (4) & (5) & (6) & (7) & (8) \\
\hline & $\begin{array}{l}\text { Revenue } \\
\text { growth }\end{array}$ & $\begin{array}{l}\text { Revenue } \\
\text { growth }\end{array}$ & $\begin{array}{l}\text { Revenue } \\
\text { growth }\end{array}$ & $\begin{array}{l}\text { Revenue } \\
\text { growth }\end{array}$ & $\begin{array}{l}\text { Asset } \\
\text { growth }\end{array}$ & $\begin{array}{l}\text { Asset } \\
\text { growth }\end{array}$ & $\begin{array}{l}\text { Asset } \\
\text { growth }\end{array}$ & Asset growth \\
\hline $\begin{array}{l}\text { Sanderson- } \\
\text { Windmei- } \\
\text { jer }\end{array}$ & 0.000 & 0.000 & 0.000 & 0.000 & 0.000 & 0.000 & 0.000 & 0.000 \\
\hline Observations & 232,662 & 232,662 & 232,662 & 232,662 & 232,662 & 232,662 & 232,662 & 232,662 \\
\hline$R$-squared & 0.054 & 0.067 & 0.066 & 0.082 & 0.119 & 0.149 & 0.133 & 0.179 \\
\hline
\end{tabular}

The dependent variable in columns 1-4 is revenue growth. The dependent variable in columns 5-8 is asset growth. The benchmark is No need group. All specifications are results estimated employing Wooldridge's (2015) modified control function. All estimations include full sets of two-digit industry dummies, 63 province dummies, and 8 dummies for owner education. Hansen $(J)$ is a test of overidentifying restrictions; the joint null hypothesis is that the instruments are valid instruments. Sanderson-Windmeijer (SW) is the tests of underidentification and weak identification. The null that the particular endogenous regressors in question is unidentified. Kleibergen-Paap is a test of matrix rank. The null that the matrix of reduced form coefficients has rank=K1. Anderson-Rubin and Stock-Wright LM $S$ are tests of overidentifying restrictions. The null that the coefficients of the endogenous regressors in the structural equation are jointly equal to zero. The figures reported in parentheses are heteroskedasticity robust standard errors, clustered by province. ***Significant at $1 \%$; **significant at 5\%; *significant at $10 \%$

To reduce the influence of the selection bias, we employ propensity score matching (PSM). This technique is motivated by the conditional independent assumption (CIA) which, if it holds its validity, is able to eliminate the selection bias after conditioning firm performance on a set of covariates (Abadie \& Imbens, 2012). To increase the ratio of successful matching between No need and the other three treatment groups, the propensity score approach first estimates the scalar function of covariates using a logistic model. We then estimate the effect of the intention/decision to borrow on firm performance by matching to the fitted values from the first step. ${ }^{6}$

The validity of the PSM estimation depends on the balancing test, which is a test for balancing property under the null hypothesis that the covariates are balanced. The results, as shown in Table 9 indicate that this balancing condition is not satisfied at $1 \%$ level of significance. As such, we also employ coarsened exact matching (CEM). This technique is slightly different from the PSM in its first step. Instead of estimating a scalar function of covariates, CEM assigns each observation a bin signature according to the covariates. Specifically, an observation is represented by properties coarsened to discrete values through a coarsening or

\footnotetext{
${ }^{6}$ We employ the Nearest Neighbour Matching, a firm in No need group is chosen as a match for a firm in one of the treatment groups (Intention, Dissatisfied, and Satisfied) in terms of the closest propensity score (or the most similar one as regards the observed characteristics).
}

binning strategy. Thus, each member is given a bin signature that will be used to exactly match other members with the same bin signature (Iacus et al., 2012). Then the CEM weights obtained from matching will be used to correct for selection bias.

The PSC and CEM results are reported in Table 9. Columns 1-6 report the average treatment effects on the treated (ATEs) using PSM technique. Columns 7-12 report the ATEs using CEM technique. Since the control group is Lower No need, the treatment effects indicate the impacts of being Satisfied, Unsatisfied, and Intention (having an intention to borrow bank loans) on revenue growth and asset growth, relative to Lower No need. In general, the ATEs are positive and statistically significant, in line with the results from the previous modelling, demonstrating the robustness of the findings. For example, taking a look at the ATEs associated with Intention group. The results obtained from CEM indicate that, on average, a firm that simply has an intention to borrow bank loans has a revenue growth rate and an asset growth rate that are $4.8 \%$ and $8.1 \%$, respectively, higher than a firm that does not want to use external finance, ceteris paribus. Meanwhile, the differences in ATEs between being dissatisfied and satisfied with bank loans are trivial $(0.6 \%$ in terms of revenue growth, and $0.3 \%$ in terms of asset growth). These results, once again, confirm the importance of the desire of using external finance, which could exert even stronger impacts on firm growth than the reduction of financial constraints. 
Table 8 Cognitive financial constraints and growth (multi-level modelling)

\begin{tabular}{|c|c|c|c|c|c|c|c|c|}
\hline & (1) & (2) & (3) & (4) & (5) & (6) & (7) & (8) \\
\hline & Revenue growth & Revenue growth & Revenue growth & Revenue growth & Asset growth & Asset growth & Asset growth & Asset growth \\
\hline \multirow[t]{2}{*}{ Intention } & $\mathbf{0 . 0 5 0} * * *$ & & & $\mathbf{0 . 0 5 4} * * *$ & $0.083 * * *$ & & & $0.069 * * *$ \\
\hline & $(0.017)$ & & & $(0.017)$ & $(0.014)$ & & & $(0.012)$ \\
\hline \multirow[t]{2}{*}{ Dissatisfied } & & $0.040 * * *$ & & $0.036 * * *$ & & $0.115 * * *$ & & $0.109 * * *$ \\
\hline & & $(0.013)$ & & $(0.012)$ & & $(0.010)$ & & $(0.009)$ \\
\hline \multirow[t]{2}{*}{ Satisfied } & & & $0.041 * * *$ & $\mathbf{0 . 0 3 8} * * *$ & & & $0.119 * * *$ & $0.118 * * *$ \\
\hline & & & $(0.011)$ & $(0.012)$ & & & $(0.009)$ & $(0.008)$ \\
\hline \multirow[t]{2}{*}{ Owner age } & $-0.003^{* * *}$ & $-0.004 * * *$ & $-0.004 * * *$ & $-0.004 * * *$ & $0.002 * *$ & -0.000 & $-0.001^{*}$ & $-0.001 * *$ \\
\hline & $(0.001)$ & $(0.001)$ & $(0.001)$ & $(0.000)$ & $(0.001)$ & $(0.000)$ & $(0.000)$ & $(0.000)$ \\
\hline \multirow[t]{2}{*}{ Owner gender } & 0.020 & -0.001 & 0.004 & -0.001 & 0.007 & 0.008 & 0.005 & 0.002 \\
\hline & (0.019) & $(0.015)$ & $(0.012)$ & $(0.010)$ & $(0.015)$ & $(0.011)$ & $(0.009)$ & $(0.007)$ \\
\hline \multirow[t]{2}{*}{ Firm age } & $-0.015^{* * *}$ & $-0.018 * * *$ & $-0.013 * * *$ & $-0.016 * * *$ & $-0.004^{* * *}$ & $-0.006^{* * *}$ & $-0.005^{* * *}$ & $-0.006^{* * *}$ \\
\hline & $(0.002)$ & $(0.001)$ & $(0.001)$ & $(0.001)$ & $(0.001)$ & $(0.001)$ & $(0.001)$ & $(0.001)$ \\
\hline \multirow[t]{2}{*}{ Firm size } & $0.061 * * *$ & $0.050 * * *$ & $0.027 * * *$ & $0.042 * * *$ & $0.105^{* * * *}$ & $0.064 * * *$ & $0.047 * * *$ & $0.047 * * *$ \\
\hline & $(0.009)$ & $(0.007)$ & $(0.006)$ & $(0.005)$ & $(0.007)$ & $(0.005)$ & $(0.004)$ & $(0.003)$ \\
\hline \multirow[t]{2}{*}{ Profitability } & $0.978 * * *$ & $1.221 * * *$ & $1.085^{* * *} *$ & $1.152 * * *$ & $0.455^{* * *} *$ & $0.458 * * *$ & $0.300 * * *$ & $0.372 * * *$ \\
\hline & $(0.080)$ & $(0.068)$ & $(0.057)$ & $(0.049)$ & $(0.064)$ & $(0.051)$ & $(0.043)$ & $(0.035)$ \\
\hline \multirow[t]{2}{*}{ Asset structure } & $-0.100 * * *$ & $-0.091^{* * *} *$ & $-0.072 * * *$ & $-0.088 * * *$ & $-0.136^{* * *}$ & $-0.198 * * *$ & $-0.211^{* * *}$ & $-0.229 * * *$ \\
\hline & $(0.036)$ & $(0.026)$ & $(0.022)$ & $(0.018)$ & $(0.028)$ & $(0.019)$ & $(0.016)$ & $(0.013)$ \\
\hline \multirow[t]{2}{*}{ Debt structure } & $0.143^{* * *}$ & $0.194 * * *$ & $0.176^{* * *}$ & $0.193 * * *$ & $0.307 * * *$ & $0.328 * * *$ & $0.330 * * *$ & $0.340 * * *$ \\
\hline & $(0.028)$ & $(0.022)$ & (0.019) & $(0.015)$ & $(0.022)$ & $(0.016)$ & $(0.014)$ & $(0.011)$ \\
\hline \multirow[t]{2}{*}{ Investment } & $0.079^{*}$ & $0.213^{*} * *$ & $0.205^{* * *}$ & $0.232 * * *$ & $0.391 * * *$ & $0.532 * * *$ & $0.507 * * *$ & $0.583 * * *$ \\
\hline & $(0.044)$ & $(0.032)$ & $(0.027)$ & $(0.022)$ & $(0.035)$ & $(0.024)$ & $(0.020)$ & $(0.016)$ \\
\hline \multirow{2}{*}{$\begin{array}{l}\text { Provincial con- } \\
\text { structions }\end{array}$} & 0.003 & -0.001 & -0.006 & $-0.012 * * *$ & -0.004 & $-0.009^{* *}$ & $-0.008^{* *}$ & $-0.010^{* * *} *$ \\
\hline & $(0.005)$ & $(0.004)$ & $(0.004)$ & $(0.004)$ & $(0.005)$ & $(0.004)$ & $(0.003)$ & $(0.004)$ \\
\hline \multirow{2}{*}{$\begin{array}{l}\text { Provincial con- } \\
\text { sumptions }\end{array}$} & -0.000 & 0.001 & $0.003 * *$ & $0.005 * * *$ & $-0.009 * * *$ & $-0.007^{* * *}$ & $-0.006^{* * *}$ & $-0.008 * * *$ \\
\hline & $(0.002)$ & $(0.001)$ & $(0.001)$ & $(0.001)$ & $(0.001)$ & $(0.001)$ & $(0.001)$ & $(0.001)$ \\
\hline \multirow[t]{2}{*}{ Distance } & -0.069 & -0.020 & -0.046 & 0.013 & 0.129 & -0.001 & -0.007 & -0.062 \\
\hline & $(0.112)$ & $(0.089)$ & $(0.088)$ & $(0.090)$ & $(0.103)$ & $(0.085)$ & $(0.071)$ & $(0.080)$ \\
\hline \multirow[t]{2}{*}{ Cumulative FDI } & -0.010 & 0.004 & 0.000 & 0.019 & -0.003 & -0.017 & -0.018 & -0.029 \\
\hline & $(0.025)$ & $(0.023)$ & $(0.023)$ & $(0.025)$ & $(0.025)$ & $(0.023)$ & $(0.019)$ & $(0.022)$ \\
\hline \multirow[t]{2}{*}{ SOE capital } & -0.236 & -0.152 & -0.077 & -0.058 & $0.363^{* * *}$ & $0.515^{* * *}$ & $0.380 * * *$ & $0.425^{* * * *}$ \\
\hline & $(0.145)$ & $(0.117)$ & $(0.109)$ & $(0.096)$ & $(0.124)$ & $(0.096)$ & $(0.084)$ & $(0.075)$ \\
\hline \multirow{2}{*}{$\begin{array}{l}\text { Local govern- } \\
\text { ance quality }\end{array}$} & -0.003 & $-0.005^{* *}$ & $-0.004 * *$ & $-0.005^{* * *}$ & $0.004^{*}$ & $0.004^{* *}$ & $0.004 * * *$ & $0.004 * * *$ \\
\hline & $(0.003)$ & $(0.002)$ & $(0.002)$ & $(0.002)$ & $(0.002)$ & $(0.002)$ & $(0.001)$ & $(0.001)$ \\
\hline VIF & 2.541 & 2.661 & 2.369 & 3.684 & 2.332 & 2.964 & 2.247 & 3.325 \\
\hline Sigma $v_{g}$ & 0.054 & 0.094 & 0.098 & 0.044 & 0.057 & 0.052 & 0.048 & 0.061 \\
\hline Sigma $e$ & 0.741 & 0.763 & 0.751 & 0.766 & 0.525 & 0.564 & 0.552 & 0.547 \\
\hline Observations & 204,135 & 204,135 & 204,135 & 204,135 & 204,135 & 204,135 & 204,135 & 204,135 \\
\hline Number of groups & 63 & 63 & 63 & 63 & 63 & 63 & 63 & 63 \\
\hline
\end{tabular}

The dependent variable in columns 1, 2, and 3 is revenue growth. The dependent variable in columns 4, 5, and 6 is asset growth. All specifications are estimated using multi-level estimator with provinces at level two and firms at level one. All estimations include full sets of two-digit industry dummies, 63 province dummies, and 8 dummies for owner education. Sigma $v_{g}$ and Sigma $e$ report the estimated random-effects parameters. The figures reported in parentheses are heteroskedasticity robust standard errors, clustered by province. $* * *$ Significant at $1 \%$; * significant at $5 \%$; *significant at $10 \%$ 


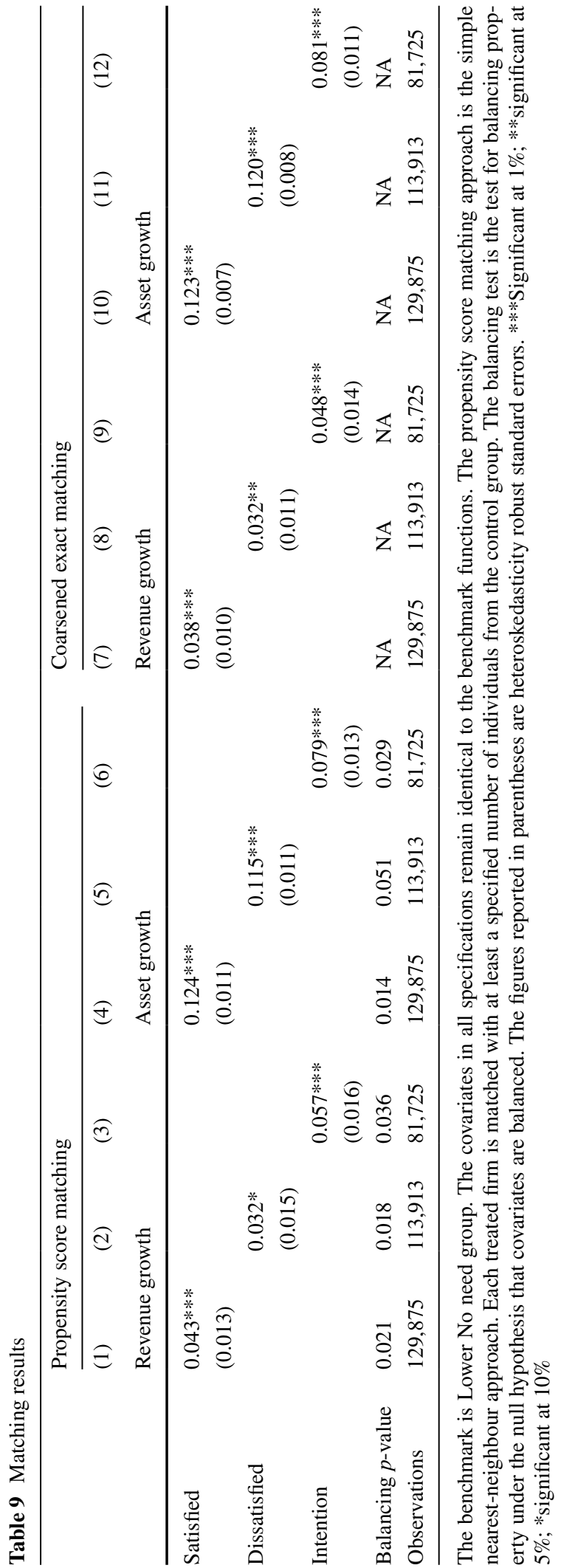

Open Access This article is licensed under a Creative Commons Attribution 4.0 International License, which permits use, sharing, adaptation, distribution and reproduction in any medium or format, as long as you give appropriate credit to the original author(s) and the source, provide a link to the Creative Commons licence, and indicate if changes were made. The images or other third party material in this article are included in the article's Creative Commons licence, unless indicated otherwise in a credit line to the material. If material is not included in the article's Creative Commons licence and your intended use is not permitted by statutory regulation or exceeds the permitted use, you will need to obtain permission directly from the copyright holder. To view a copy of this licence, visit http://creativecommons.org/licenses/by/4.0/.

\section{References}

Abadie, A., \& Imbens, G. W. (2011). Bias-corrected matching estimators for average treatment effects. Journal of Business \& Economic Statistics, 29(1), 1-11.

Abadie, A., \& Imbens, G. W. (2012). Matching on the estimated propensity score. National Bureau of Economic Research.

Agius Vallejo, J., \& Canizales, S. L. (2016). Latino/a professionals as entrepreneurs: How race, class, and gender shape entrepreneurial incorporation. Ethnic \& Racial Studies, 39(9), 1637-1656.

Aidis, R. (2005). Institutional barriers to small- and mediumsized enterprise operations in transition countries. Small Business Economics, 25(4), 305-318.

Anton, J. J., \& Yao, D. A. (2002). The sale of ideas: Strategic disclosure, property rights, and contracting. The Review of Economic Studies, 69(3), 513-531.

Anwar, S., \& Nguyen, L. (2011). Financial development and economic growth in Vietnam. Journal of Economics \& Finance, 35(3), 348-360.

Ayyagari, M., Demirgüç-Kunt, A., \& Maksimovic, V. (2010). Formal versus informal finance: Evidence from China. Review of Financial Studies, 23(8), 3048-3097.

Baker, T., \& Nelson, R. E. (2005). Creating something from nothing: Resource construction through entrepreneurial bricolage. Administrative Science Quarterly, 50(3), 329-366.

Baños-Caballero, S., García-Teruel, P. J., \& MartínezSolano, P. (2010). Working capital management in SMEs. Accounting \& Finance, 50(3), 511-527.

Bardasi, E., Sabarwal, S., \& Terrell, K. (2011). How do female entrepreneurs perform? Evidence from three developing regions. Small Business Economics, 37(4), 417-441.

Baron, R. (2006). Opportunity recognition as pattern recognition: How entrepreneurs 'connect the dots' to identify new business opportunities. Academy of Management Perspectives, 20(1), 104-119.

Baron, R. A. (2007). Behavioral and cognitive factors in entrepreneurship: Entrepreneurs as the active element in new venture creation. Strategic Entrepreneurship Journal, 1(1-2), 167-182.

Barton, S. L., \& Gordon, P. J. (1987). Corporate strategy: Useful perspective for the study of capital structure? Academy of Management Review, 12(1), 67-75. 
Baulch, B., TruongThi Kim, C., Haughton, D., \& Haughton, J. (2007). Ethnic minority development in Vietnam. Journal of Development Studies, 43(7), 1151-1176.

Baumann, J., \& Kritikos, A. S. (2016). The link between R\&D, innovation and productivity: Are micro firms different? Research Policy, 45(6), 1263-1274.

Block, J. H. (2012). R\&D investments in family and founder firms: An agency perspective. Journal of Business Venturing, 27(2), 248-265.

Bond, S., \& Meghir, C. (1994). Financial constraints and company investment. Fiscal Studies, 15(2), 1-18.

Bond, S., \& Van Reenen, J. (2007). Microeconometric models of investment and employment. In J. H. James \& E. L. Edward (Eds.), Handbook of econometrics (Vol. 6, pp. 4417-4498). Elsevier.

Boudreaux, C. J., Nikolaev, B. N., \& Klein, P. (2019). Sociocognitive traits and entrepreneurship: The moderating role of economic institutions. Journal of Business Venturing, 34(1), 178-196.

Brown, J. D., Crespi, G. A., Iacovone, L., \& Marcolin, L. (2018). Decomposing firm-level productivity growth and assessing its determinants: Evidence from the Americas. The Journal of Technology Transfer, 43(6), 1571-1606.

Busenitz, L. W., Gómez, C., \& Spencer, J. W. (2000). Country institutional profiles: Unlocking entrepreneurial phenomena. Academy of Management Journal, 43(5), 994-1003.

Carpenter, R. E., \& Guariglia, A. (2008). Cash flow, investment, and investment opportunities: New tests using UK panel data. Journal of Banking and Finance, 32(9), 1894-1906.

Carpenter, R. E., \& Petersen, B. C. (2002). Is the growth of small firms constrained by internal finance? Review of Economics \& Statistics, 84(2), 298-309.

Carreira, C., \& Silva, F. (2010). No deep pockets: Some stylized empirical results on firms' financial constraints. Journal of Economic Surveys, 24(4), 731-753.

Carter, S., Mwaura, S., Ram, M., Trehan, K., \& Jones, T. (2015). Barriers to ethnic minority and women?s enterprise: Existing evidence, policy tensions and unsettled questions. International Small Business Journal, 33(1), 49-69.

Cassar, G. (2010). Are individuals entering self-employment overly optimistic? An empirical test of plans and projections on nascent entrepreneur expectations. Strategic Management Journal, 31(8), 822-840.

Claessens, S. (2006). Access to financial services: A review of the issues and public policy objectives. World Bank Research Observer, 21(2), 207-240.

Cleary, S., Povel, P., \& Raith, M. (2007). The U-shaped investment curve: Theory and evidence. Journal of Financial \& Quantitative Analysis, 42(1), 1-39.

Comegys, C. (1976). Cognitive dissonance and entrepreneurial behavior. Journal of Small Business Management, 14, $1-6$.

Cressy, R., \& Olofsson, C. (1997). The financial conditions for Swedish SMEs: Survey and research agenda. Small Business Economics, 9(2), 179-194.

Dinh, Q. H., Dufhues, T. B., \& Buchenrieder, G. (2012). Do connections matter? Individual social capital and credit constraints in Vietnam. European Journal of Development Research, 24(3), 337-358.
Du, J., Guariglia, A., \& Newman, A. (2015). Do social capital building strategies influence the financing behavior of Chinese private small and medium-sized enterprises? Entrepreneurship: Theory \& Practice, 39(3), 601-631.

Efendic, A., Mickiewicz, T., \& Rebmann, A. (2015). Growth aspirations and social capital: Young firms in a post-conflict environment. International Small Business Journal, 33(5), 537-561.

Estrin, S., Korosteleva, J., \& Mickiewicz, T. (2013). Which institutions encourage entrepreneurial growth aspirations? Journal of Business Venturing, 28(4), 564-580.

Fazzari, S. M., \& Petersen, B. C. (1993). Working capital and fixed investment: New evidence on financing constraints. RAND Journal of Economics, 24(3), 328-342.

Fraser, S., Bhaumik, S. K., \& Wright, M. (2015). What do we know about entrepreneurial finance and its relationship with growth? International Small Business Journal, 33(1), $70-88$.

Fritsch, M., \& Mueller, P. (2004). Effects of new business formation on regional development over time. Regional Studies, 38(8), 961-975.

Fritsch, M., \& Mueller, P. (2007). The persistence of regional new business formation-activity over time-Assessing the potential of policy promotion programs. Journal of Evolutionary Economics, 17(3), 299-315.

Fritsch, M., \& Wyrwich, M. (2014). The long persistence of regional levels of entrepreneurship: Germany, 1925-2005. Regional Studies, 6, 955-973.

Guariglia, A. (2008). Internal financial constraints, external financial constraints, and investment choice: Evidence from a panel of UK firms. Journal of Banking and Finance, 32(9), 1795-1809.

Guariglia, A., \& Liu, P. (2014). To what extent do financing constraints affect Chinese firms' innovation activities? International Review of Financial Analysis, 36(12), 223-240.

Guariglia, A., Liu, X., \& Song, L. (2011). Internal finance and growth: Microeconometric evidence on Chinese firms. Journal of Development Economics, 96(1), 79-94.

Hessels, J., Thurik, R., \& Van Gelderen, M. (2008). Drivers of entrepreneurial aspirations at the country level: The role of start-up motivations and social security. International Entrepreneurship and Management Journal, 4(4), 401-417.

Hutchinson, R. W. (1995). The Capital structure and investment decisions of the small owner-managed firm: Some exploratory issues. Small Business Economics, 7(3), 231-239.

Iacus, S. M., King, G., \& Porro, G. (2012). Causal inference without balance checking: Coarsened exact matching. Political Analysis, 20(1), 1-24.

Invernizzi, A. C., Menozzi, A., Passarani, D. A., Patton, D., \& Viglia, G. (2017). Entrepreneurial overconfidence and its impact upon performance. International Small Business Journal, 35(6), 709-728.

Jovanovic, B. (1982). Selection and the evolution of industry. Econometrica, 50(3), 649-670.

Kolstad, I., \& Wiig, A. (2015). Education and entrepreneurial success. Small Business Economics, 44(4), 783-796.

Leong, N. (2016). Identity entrepreneurs. California Law Review, 104(6), 1333-1399. 
Liu, Y., Li, Y., Hao, X., \& Zhang, Y. (2019). Narcissism and learning from entrepreneurial failure. Journal of Business Venturing, 34(3), 496-512.

Mitchell, R. K., Smith, J. B., Morse, E. A., Seawright, K. W., Peredo, A. M., \& McKenzie, B. (2002). Are entrepreneurial cognitions universal? Assessing entrepreneurial cognitions across cultures. Entrepreneurship: Theory and Practice, 26(4), 9-25.

Nguyen, B. (2018). Is a bit more experience bad? The role of entrepreneurial experience on investment rate. International Journal of Entrepreneurial Behavior \& Research, 25(6), 1166-1187.

Nguyen, B. (2019). Entrepreneurial reinvestment: Local governance, ownership, and financing matter-evidence from Vietnam. Journal of Small Business Management, 57(2), 323-349.

Nguyen, B., \& Canh, N. P. (2020). Formal and informal financing decisions of small businesses. Article in Press.

Nguyen, B., Mickiewicz, T., \& Du, J. (2018a). Local governance and business performance in Vietnam: The transaction costs perspective. Regional Studies Regional Studies, 52(4), 542-557.

Nguyen, B., Mickiewicz, T., \& Du, J. (2018b). Local governance and business performance in Vietnam: The transaction costs perspective. Regional Studies, 52(4), 542-557.

Nguyen, H.-T.-M., Kompas, T., Breusch, T., \& Ward, M. B. (2017a). Language, mixed communes, and infrastructure: Sources of inequality and ethnic minorities in Vietnam. World Development, 96, 145-162.

Nguyen, H.-T.-M., Kompas, T., Breusch, T., \& Ward, M. B. (2017b). Language, mixed communes, and infrastructure: Sources of inequality and ethnic minorities in Vietnam. World Development, 96(8), 145-162.

Nguyen, T. T., \& van Dijk, M. A. (2012). Corruption, growth, and governance: Private vs. state-owned firms in Vietnam. Journal of Banking and Finance, 36(11), 2935-2948.

Politis, D. (2005). The process of entrepreneurial learning: A conceptual framework. Entrepreneurship: Theory \& Practice, 29(4), 399-424.

Santarelli, E., \& Tran, H. T. (2016). Diversification strategies and firm performance in Vietnam: Evidence from parametric and semi-parametric approaches. Economics of Transition, 24(1), 31-68.

Scott, W. R. (1995). Institutions and organizations Thousand Oaks, Calif. Sage.

Scott, W. R. (2014). Institutions and organizations: Ideas, interests and identities. Sage.

Su, T. D., \& Bui, T. M. H. (2017). Government size, public governance and private investment: The case of Vietnamese provinces. Economic Systems, 41(4), 651-666.

Thompson, P., \& Wenyu, Z. (2015). Foreign direct investment and the SME sector. International Journal of Entrepreneurial Behaviour \& Research, 21(1), 50-75.

Tran, H. T., \& Santarelli, E. (2014). Capital constraints and the performance of entrepreneurial firms in Vietnam. Industrial and Corporate Change, 23(3), 827-864.

Turner, S., \& Nguyen, P. A. (2005). Young entrepreneurs, social capital and "Doi Moi" in Hanoi, Vietnam. Urban Studies, 42(10), 1693-1710.

Wheeler, C. (2015). Vietnam. The cham of Vietnam: History, society and art. Journal of Southeast Asian Study, 43(6), 396-398.

Williamson, O. E. (2000). The new institutional economics: Taking stock, looking ahead. Journal of Economic Literature, 38(3), 595-613. http://www.aeaweb.org/jel/index. php.

Wooldridge, J. M. (2010). Econometric analysis of cross section and panel data. MIT Press.

Wooldridge, J. M. (2015). Control function methods in applied econometrics. Journal of Human Resources, 50(2), $420-445$.

Zhou, W. (2017). Institutional environment, public-private hybrid forms, and entrepreneurial reinvestment in a transition economy. Journal of Business Venturing, 32(2), 197-214.

Zucchella, A., Palamara, G., \& Denicolai, S. (2007). The drivers of the early internationalization of the firm. Journal of World Business, 42(3), 268-280.

Publisher's note Springer Nature remains neutral with regard to jurisdictional claims in published maps and institutional affiliations. 